\title{
Amended diagnosis and redescription of Pristimantis marmoratus (Boulenger, 1900) (Amphibia: Craugastoridae), with a description of its advertisement call and notes on its breeding ecology and phylogenetic relationships
}

\author{
Philippe J.R. KOK ${ }^{1, *}$, Raheleh DEZFOULIAN ${ }^{2}$, D. Bruce MEANS ${ }^{3}$, \\ Antoine FOUQUET ${ }^{4} \&$ César L. BARRIO-AMORÓS ${ }^{5}$ \\ ${ }^{1,2}$ Amphibian Evolution Lab, Biology Department, Vrije Universiteit Brussel, \\ 2 Pleinlaan, B-1050 Brussels, Belgium. \\ ${ }^{3}$ Coastal Plains Institute and Land Conservancy, 1313 Milton Street, Tallahassee, Florida 32303, USA. \\ ${ }^{4}$ Laboratoire Écologie, Évolution, Interactions des Systèmes Amazoniens (USR 3456 LEEISA), \\ Université de Guyane, CNRS Guyane, Cayenne, French Guiana. \\ ${ }^{5}$ Doc Frogs Expeditions, Apartado Postal 220-8000, San José, Pérez Zeledón, \\ San Isidro del General, 11901 Costa Rica. \\ *Corresponding author: philippe.kok@vub.be \\ ${ }^{2}$ Email: r.dezfoulian@gmail.com \\ ${ }^{3}$ Email: means@bio.fsu.edu \\ ${ }^{4}$ Email: fouquet.antoine@gmail.com \\ ${ }^{5}$ Email: cesarlba@yahoo.com

\footnotetext{
${ }^{1}$ urn:lsid:zoobank.org:author:62BA0CB3-FB94-407F-90A1-06AB6401B911

${ }^{2}$ urn:lsid:zoobank.org:author:3A962C0A-0E66-4683-B18E-B2D7342A347A

${ }^{3}$ urn:1sid:zoobank.org:author:1D1D6AAE-EF92-4F19-92AF-59CE393CB0E9

${ }^{4}$ urn:1sid:zoobank.org:author:F60FCBAF-0F63-4BFA-8827-FD87D569885C

${ }^{5}$ urn:1sid:zoobank.org:author:7D6F60FB-056A-487E-A135-34B21302DE43
}

\begin{abstract}
The frog Pristimantis marmoratus was originally described as Hylodes marmoratus by George A. Boulenger in 1900 based on a single specimen reported to have been collected at the foot of Mount Roraima in Guyana in 1898. We herein discuss the exact location of the type locality of P. marmoratus and provide a redescription of the species based on new material from Kaieteur National Park and from the slopes of Maringma-tepui in Guyana. We also describe the previously unknown vocalization and breeding ecology of the species, and conducted an exploratory molecular analysis of the phylogenetic relationships within the genus Pristimantis represented by the members of the "unistrigatus species group" in the Guiana Shield. Pristimantis marmoratus is a small-sized species mainly distinguished from its known Guiana Shield congeners by the combination of F I $<$ II, SVL $\leq 20.4$ in males, presence of vocal slits in males, granular/pustulate dorsal skin with well-developed scapular ridges, basal webbing between fingers, fringes on fingers and toes, crossed iris, diffuse yellow or pale green wash on groin, and absence of flashy colour on axillary/pre-axillary region. The advertisement call consists of a single note repeated at a rate of ca 11 calls/min with a dominant frequency ranging from 2756 to $3101 \mathrm{~Hz}$.
\end{abstract}


Pristimantis marmoratus is primarily arboreal, exclusively active at dusk, and probably restricted to the pristine rainforests of the Pantepui uplands and highlands, east of the Gran Sabana between ca 600 and $1800 \mathrm{~m}$ above sea level. Preliminary molecular analyses recovered Pristimantis marmoratus as sister to an unnamed species from the Eastern Guiana Shield. On grounds of the newly established distributional extent we suggest maintaining the IUCN conservation status as Least Concern.

Keywords. Anura, Guiana Shield, Pantepui, Systematics, Terrarana.

Kok P.J.R., Dezfoulian R., Means D.B., Fouquet A. \& Barrio-Amorós C.L. 2018. Amended diagnosis and redescription of Pristimantis marmoratus (Boulenger, 1900) (Amphibia: Craugastoridae), with a description of its advertisement call and notes on its breeding ecology and phylogenetic relationships. European Journal of Taxonomy 397: 1-30. https://doi.org/10.5852/ejt.2018.397

\section{Introduction}

Pristimantis marmoratus (Boulenger, 1900) is the oldest described Guiana Shield member of what has later been referred to as the "unistrigatus group" (see Hedges et al. 2008; Kok et al. 2011; Kok 2013). As often with old descriptions, the original description of Hylodes marmoratus is not comprehensive enough to allow for an unambiguous diagnosis of the species compared to most of the many other members of the genus. Consequently, many available phylogenetic analyses have been based on misidentified specimens and are thus misleading for the position of P. marmoratus sensu stricto.

Pristimantis marmoratus is currently reported as widespread in the Guiana Shield, occurring from Amazonian Venezuela to French Guiana (e.g., Rivero 1961; Lescure 1976; Lescure 1981; BarrioAmorós 1998; Lescure \& Marty 2001; MacCulloch \& Lathrop 2009; Avila-Pires et al. 2010; Ouboter \& Jairam 2012; Frost 2016). MacCulloch et al. (2010) mentioned that the species also occurs in Amazonas State in Brazil, and described it as being "a terrestrial leaf-litter species found in tropical lowland and montane forest. It breeds by direct development, but the egg deposition site is not known. It is adaptable to human intervention". However, some recent works challenged the view of P. marmoratus being as widespread as currently reported, and suggested instead that the name could have been applied to a number of undescribed species (e.g., Fouquet et al. 2007, 2013, Kok 2013). The name marmoratus seems to have been occasionally used for any small brown, hard to identify Pristimantis in north-eastern South America, and the lack of comparative specimens from close to the type locality has prevented the improvement of the species diagnosis.

As mentioned earlier, the briefness of some original species descriptions is clearly an obstacle to accurate species identification. Too brief descriptions contribute to the confusion among morphologically similar taxa and make new species descriptions more challenging (see e.g., example Kok et al. 2006; Kok et al. 2013; Fouquet et al. 2016). Loose descriptions also prevent the correct evaluation of conservation recommendations because identification problems affect the accuracy of the species distribution. Therefore, we believe it is an important prerequisite to redescribe these poorly defined taxa and redefine their exact geographical distribution, ultimately facilitating the description of still unnamed related taxa.

Based on new material collected in western and west-central Guyana, and direct comparison with the holotype of Pristimantis marmoratus (BMNH 1947.2.16.92, formerly 99.3.25.19), we here provide a morphological redescription and amended diagnosis of the species. We also describe the call of $P$. marmoratus for the first time, report on its previously unknown breeding ecology, discuss an exploratory molecular analysis of the phylogenetic relationships within the genus Pristimantis represented by the members of the "unistrigatus species group" occurring in the Guiana Shield, and examine the IUCN Red List Category of the species. 
All Pristimantis species from the Guiana Shield highlands have historically been assigned to the "unistrigatus species group" (sensu Hedges et al. 2008). Although Padial et al. (2014) considered these species as unassignable to any group (the unistrigatus group being polyphyletic), we find taxonomically practical to use this artificial grouping as a working basis to compare the Guiana Shield Pristimantis species having the first finger shorter than the second with other Pristimantis species groups in the area.

\section{On the type locality of Pristimantis marmoratus (Boulenger, 1900)}

According to Boulenger (1900), the holotype of Pristimantis marmoratus is "from the foot of Mt. Roraima, 3500 feet" (ca 1067 m elevation) in Guyana. The specimen was collected by F.V. McConnell and J.J. Quelch, two British biologists and explorers, during an expedition to the summit of Mount Roraima led between August and October 1898. Although - according to our knowledge - the exact route taken by McConnell and Quelch during that trip is not illustrated on any map, their itinerary can be inferred from the literature. In correspondence between McConnell and Boulenger (Boulenger 1900), the former stated: "The specimens were obtained by Mr. J. J. Quelch and myself on our second expedition to Roraima in August, September, and October, 1898. The route taken on this occasion was by the Mazaruni and Curubung rivers to the Falls of Macrobah, a boat-journey of twenty days, and thence by land to a point on the Upper Mazaruni where that river flows at a height of 1300 feet. Small bark-canoes were here obtained, and after three days' journey up the Cako and Aruparu we arrived at the commencement of the trail to Roraima. With the exception of the last twenty miles, the whole journey, which occupied forty days, lay through thick forest."

Shortly after, Brown et al. (1901) mentioned the following about McConnell and Quelch's expedition: "... the Kako was paddled up until a point was reached about twenty miles north-east of Roraima, and thence, leaving the canoes, a track through dense forest was taken until, in the second week of October, the south-eastern face of the mountain was reached."

Quelch (in Chubb 1921) provided a detailed overview of their itinerary (unfortunately not mapped). However, it is often difficult to locate some of the small creeks, waterfalls, and Amerindian settlements he mentioned. It nevertheless leaves no doubt that the expedition reached the southern edge of Roraima from the east, travelling through Guyana, then entering Brazil most likely south, or slightly east, of Maringma-tepui, and finally entering Venezuela. Quelch (in Chubb 1921) wrote: “... and it was with great joy that we at last came out on continuous savannah, and from a high elevation had the great range of mountains in full view - the vertical-walled Roraima before us, with smaller Roraimas on the right; the rugged pile of Marima behind; and the beautiful Sun Mountain, with its peaked dome, its terraced slopes and sharp edges, with varying light and shade all over it, away on our left; and far away in the blue distance the high plateaux of Brazil." This, and the fact that Quelch mentions that the expedition team crossed the Cotinga River (which lies in the extreme north of the Roraima State of Brazil), indicates that the team entered Venezuela northwest of Uei-tepui (also known as Cerro El Sol, called "Sun Mountain" by Quelch, and which indeed has a peaked dome).

The path taken by Quelch and McConnell thus likely passed south of Maringma-tepui in Guyana and from there proceeded west up the Cotinga River in Brazil and then into what is now part of La Gran Sabana in Venezuela following well-travelled Amerindian trails that Schomburgk used. They probably ascended Kukenán River to a point about $8.0 \mathrm{~km}$ from the southern cliffs of Mt. Roraima, which is at 3500 feet elevation, and by the late 1920s was forested (Tate 1930). If 3500 feet elevation is reasonable, this is the closest approach to Mt. Roraima at that elevation and we believe near where the type locality must be. Today the rainforest has long since been converted into low diversity grassland by frequent Amerindian burning at all seasons. 
Phelps (1938) correctly stated that the collection reported in Boulenger (1900) from Guyana was actually obtained in Venezuela.

\section{Material and methods}

\section{Fieldwork and deposition of specimens}

The newly collected specimens of Pristimantis marmoratus are from close to the type locality, namely the slopes of Maringma-tepui ( $5^{\circ} 12^{\prime} 38^{\prime \prime} \mathrm{N}, 60^{\circ} 33^{\prime} 59^{\prime \prime} \mathrm{W}, 1060-1376 \mathrm{~m}$ elevation, ca $15 \mathrm{~km}$ airline from Mt. Roraima; Fig. 1), Cuyuni-Mazaruni District, Guyana, where two adult males and one juvenile were secured in November 2007, and from a locality named Amu Trail in the south-eastern part of Kaieteur National Park $\left(5^{\circ} 08^{\prime} \mathrm{N}, 59^{\circ} 24^{\prime} \mathrm{W}\right.$, ca $150 \mathrm{~km}$ airline from Mt. Roraima, ca $630 \mathrm{~m}$ elevation; Fig. 1), Potaro-Siparuni District, Guyana where four adult individuals (three males, one female) were collected in June 2006. Specimens were collected by hand, euthanized by immersion in a $2 \%$ Xylocaine solution, fixed in $10 \%$ formalin for several days and then transferred to $70 \%$ ethanol for permanent storage. A piece of liver and/or thigh muscle was taken from specimens prior to fixation and preserved in $95 \%$ ethanol for later molecular analyses. Specimens were deposited in the collections of the Institut Royal des Sciences Naturelles de Belgique (IRSNB) and tissue samples were deposited in the Amphibian Evolution Lab, Biology Department, Vrije Universiteit Brussel.

\section{Morphology}

The terminology for morphological characters mostly follows Duellman \& Lehr (2009) and most recent Pristimantis descriptions from the Guiana Shield (e.g., Kok 2013; Fouquet et al. 2013). Colour in life is described from digital photographs and field notes. Sex and maturity were determined by the presence/absence of vocal slit(s). All morphometric data were taken from the preserved specimens by

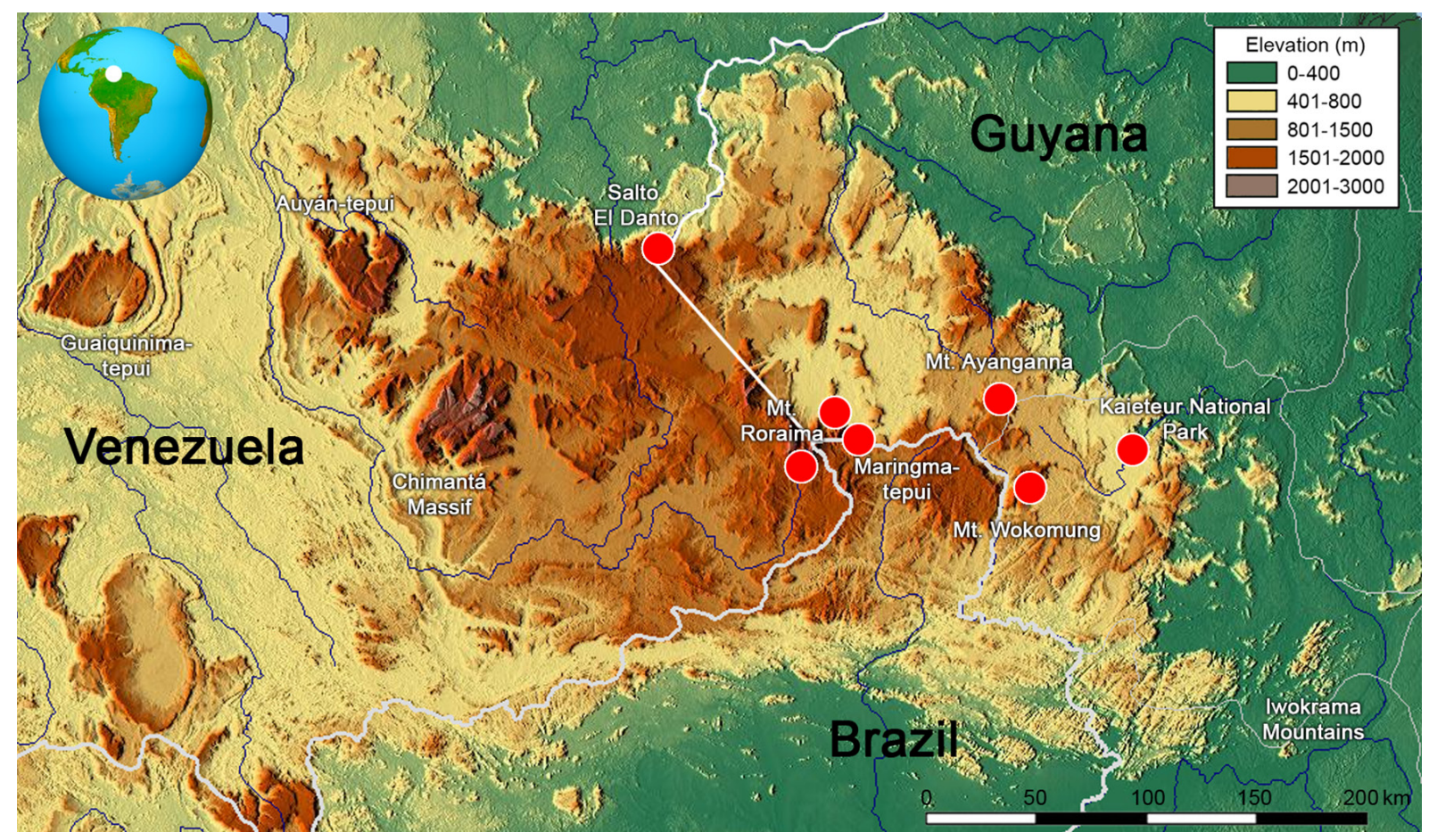

Fig. 1. Map of the Eastern Pantepui District showing the known distribution of Pristimantis marmoratus (Boulenger, 1900). Red dots denote localities of confirmed occurrence based either on museum specimens or colour photographs. 
the same person (RD; except for the holotype: taken by PJRK) to the nearest $0.01 \mathrm{~mm}$ and rounded to the nearest $0.1 \mathrm{~mm}$, under a Leica stereo dissecting microscope using an electronic digital caliper.

Abbreviations and standard measurements for adults are as follows:

$\begin{array}{ll}\text { EL } & =\text { eye length } \\ \text { EN } & =\text { eye to naris distance from anterior corner of eye to posterior margin of naris } \\ \text { FL } & =\text { foot length from proximal edge of outer metatarsal tubercle to tip of Toe IV } \\ \text { HAND } & =\text { hand length from proximal edge of palmar tubercle to tip of Finger III } \\ \text { HL } & =\text { head length from angle of jaw to tip of snout } \\ \text { HW } & =\text { head width at level of angle of jaws } \\ \text { IN } & =\text { internarial distance } \\ \text { IO } & =\text { interorbital distance } \\ \text { SL } & =\text { snout length from anterior corner of eye to tip of snout } \\ \text { SVL } & =\text { snout-vent length } \\ \text { TIL } & =\text { tibia length from outer edge of flexed knee to heel } \\ \text { TYM } & =\text { greatest length of tympanum from its anterior margin to its posterior margin } \\ \text { WFD } & =\text { width of disc on Finger III } \\ \text { WTD } & =\text { width of disc on Toe IV }\end{array}$

The newly acquired specimens were assigned to Pristimantis marmoratus based on morphological congruence with the holotype. Molecular sequence data from these specimens (two of them already available at GenBank) were used to reassign misidentified specimens (see Table 1). Because of the cryptic nature of this group, and to avoid adding more confusion, we restricted the number of specimens used in the redescription to specimens for which identification was unambiguously confirmed by molecular data on mitochondrial 16S sequences (see DNA barcoding below and Appendix 3). Specimens for which molecular data were unavailable and that we identified with confidence as Pristimantis marmoratus based on photographs and/or museum specimens were used to infer the distribution of the species, but were omitted from the morphological measurements and analysis.

\section{Bioacoustics}

The advertisement call of Pristimantis marmoratus was recorded at a distance of ca one meter from two calling males collected in Kaieteur National Park: IRSNB 14471 recorded on 26 Jun. 2006 at 6:30 pm, and IRSNB 14472 recorded on 28 Jun. 2006 at 6:00 pm. Calls were recorded on a Maxell DM60 digital audiotape using a Sony ECM-MS907 microphone attached to a DAT Sony TCD-D100 recorder. Call motivation was deemed high since several males were calling at the same location at regular intervals; air temperature at the call sites was measured with a Hanna digital $\mathrm{pH} /$ thermometer and was $24^{\circ} \mathrm{C}$. Only three (IRSNB 14471) and 13 (IRSNB 14472) calls could be recorded. We followed a note-centred approach (Köhler et al. 2017), and calls were analysed at a sampling rate of $44100 \mathrm{~Hz}$ using the software Raven v. 1.4 (Charif et al. 2010). Temporal variables measured are some of those summarized in Kok \& Kalamandeen (2008) and included: call duration; inter-call silent interval (end of one call to beginning of the next); and call rate (number of calls per minute). The dominant frequency of the note (frequency where most sound energy is concentrated within the whole power spectrum) was calculated in Raven v. 1.4 using the "Max Freq (Hz)" measurement tool (Charif et al. 2010). Oscillograms and spectrograms were obtained using Raven v. 1.4 and Seewave v. 1.6.4 (Sueur et al. 2008) in the R statistical computing environment (R Development Core Team 2015).

\section{Molecular phylogenetic analysis}

A comprehensive phylogenetic analysis of the large polyphyletic "unistrigatus species group" (Hedges et al. 2008) is beyond the scope of this paper, instead we conducted an exploratory molecular analysis of the phylogenetic relationships within the genus Pristimantis represented by the members of the 
Table 1. Reidentified terminal species names of GenBank. Accession numbers in bold represent Pristimantis marmoratus (Boulenger, 1900). Asterisks highlight sequences of specimens we examined and that correspond to the morphology of the holotype.

\begin{tabular}{|c|c|c|c|}
\hline $\begin{array}{c}\text { GenBank } \\
\text { accession } \\
\text { number }\end{array}$ & Original name & Voucher specimen & Reidentified name \\
\hline EU186723 & Pristimantis pulvinatus & KU 181015 & Pristimantis marmoratus (Boulenger, 1900) \\
\hline EU186716 & Pristimantis sp. & ROM 43302 & Pristimantis marmoratus (Boulenger, 1900) \\
\hline JQ742166* & Pristimantis aff. pulvinatus A & IRSNB 14471 & Pristimantis marmoratus (Boulenger, 1900) \\
\hline JQ742167* & Pristimantis aff. pulvinatus A & IRSNB 12862 & Pristimantis marmoratus (Boulenger, 1900) \\
\hline JQ742339* & Pristimantis aff. pulvinatus A & IRSNB 12862 & Pristimantis marmoratus (Boulenger, 1900) \\
\hline JQ742164 & Pristimantis aff. pulvinatus $\mathrm{B}$ & IRSNB 15786 & Pristimantis pulvinatus (Rivero, 1968) \\
\hline JQ742338 & Pristimantis aff. pulvinatus $\mathrm{B}$ & IRSNB 15786 & Pristimantis pulvinatus (Rivero, 1968) \\
\hline JQ742165 & Pristimantis aff. pulvinatus $\mathrm{B}$ & IRSNB 15634 & Pristimantis pulvinatus (Rivero, 1968) \\
\hline EU201063 & Pristimantis marmoratus & “110BM" & Pristimantis sp. 1 (Fouquet et al. 2013) \\
\hline JN690707 & Pristimantis marmoratus & "110BM" & Pristimantis sp. 1 (Fouquet et al. 2013) \\
\hline JN690708 & Pristimantis marmoratus & $" 21 \mathrm{AF} "$ & Pristimantis sp. 1 (Fouquet et al. 2013) \\
\hline JN691315 & Pristimantis marmoratus & "21AF" & Pristimantis sp. 1 (Fouquet et al. 2013) \\
\hline JN692010 & Pristimantis marmoratus & "21AF" & Pristimantis sp. 1 (Fouquet et al. 2013) \\
\hline EU186692 & Pristimantis marmoratus & ROM 43913 & Pristimantis saltissimus (Means \& Savage, 2007) \\
\hline EU201062 & Pristimantis marmoratus & “77MC" & Pristimantis sp. 1 (Fouquet et al. 2013) \\
\hline EU201063 & Pristimantis marmoratus & “110BM" & Pristimantis sp. 1 (Fouquet et al. 2013) \\
\hline JQ742170 & Pristimantis cf. marmoratus & VUB 3626 & Pristimantis inguinalis (Parker, 1940) \\
\hline JQ742342 & Pristimantis cf. marmoratus & VUB 3626 & Pristimantis inguinalis (Parker, 1940) \\
\hline
\end{tabular}

"unistrigatus group" of Hedges et al. (2008) occurring in the Guiana Shield. This was with the aim of testing whether P. marmoratus is distinct from all other regional members of the group for which molecular data are available. To do so, we retrieved all the $16 \mathrm{~S}$ sequences available at GenBank for members of that group in the Guiana Shield, including two sequences of specimens that we assigned to P. marmoratus based on morphology, and a sequence of P. chiastonotus Lynch \& Hoogmoed, 1977 (conspicillatus group) to be used as outgroup. These 39 sequences were aligned with MAFFT v. 7 (Katoh \& Standley 2013) and overlapped over 438 base pairs (bp), which were used for the phylogenetic analysis. We conducted a Bayesian analysis (BA) with MrBayes v. 3.1 (Huelsenbeck \& Ronquist 2001) using the GTR $+\mathrm{I}+\mathrm{G}$ substitution model as determined by jModeltest v. 2.0 (Darriba et al. 2012). The BA consisted of a $10 \times 10^{6}$ generations run starting with random trees and 4 Markov chains (one cold) sampled every 1000 generations. Adequate burn-in (the first 1000 sampled generations) was determined by examining likelihood scores of the heated chains for convergence on stationarity as well as the effective sample size of values in Tracer v. 1.5 (Rambaut \& Drummond 2007). All parameters had effective sample sizes (ESS) largely over 200. Results were visualized and edited in FigTree v. 1.4.1 (Rambaut 2014). We considered relationships to be strongly supported when posterior probabilities were equal to or higher than 0.95 .

We also calculated p-distances (pairwise deletion) among major lineages recovered from the phylogenetic analysis using MEGA 5 (Tamura et al. 2011). 


\title{
DNA barcoding
}

DNA barcoding was used to unambiguously confirm the morphological identification of specimens that we assigned to the nominal species, and for which DNA sequences were not yet available at GenBank. Total genomic DNA was extracted from liver or thigh muscle using the Qiagen DNeasy ${ }^{\circledR}$ Tissue Kit following the manufacturer's instructions. The targeted "barcoding" fragment of 16S rDNA (ca $560 \mathrm{bp}$; Vences et al. 2005) was amplified and sequenced using the primers described by Simon et al. (1994) as modified by Bossuyt \& Milinkovitch (2000) under previously described PCR conditions (Roelants et al. 2007). PCR products were checked on a $1 \%$ agarose gel and were sent to BaseClear (Leiden, The Netherlands) for purification and sequencing. These new sequences have been deposited in GenBank under the accession numbers MF037218-MF037223 (Appendix 3).

Taxonomy follows Padial et al. (2014). Institutional acronyms follow Frost (2016).

\section{Results}

\author{
Order Anura Fischer von Waldheim, 1813 \\ Superfamily Brachycephaloidea Günther, 1858 \\ Family Craugastoridae Hedges, Duellman \& Heinicke, 2008 \\ Genus Pristimantis Jiménez de la Espada, 1870
}

Pristimantis marmoratus (Boulenger, 1900)

Figs 2-5, 6D

\section{Diagnosis}

Pristimantis marmoratus (Boulenger, 1900) has historically been assigned to the polyphyletic "unistrigatus species group" (sensu Hedges et al. 2008), which is mainly characterized by having Finger I shorter than II, Toe V longer than III, extending to the distal edge of the distal subarticular tubercle of Toe IV when toes are adpressed, and by the absence of cranial crests and the presence of vomerine teeth. Pristimantis marmoratus is characterized by the following unique combination of characters:

(1) body small, adult males 17.6-20.4 mm SVL $(\mathrm{n}=5)$, adult female $27.9 \mathrm{~mm} \mathrm{SVL}(\mathrm{n}=1)$;

(2) dorsal skin granular/pustulate, usually with distinctly enlarged tubercles (less pustulate in female), belly skin granular (granules not as closely set as in areolate skin sensu Duellman \& Lehr 2009), sometimes becoming smooth in preservative;

(3) presence of well-developed oblique scapular ridges in males (less prominent in female);

(4) tympanum present, tympanic membrane not or only poorly differentiated, and tympanic annulus only partially visible externally, obscured by supratympanic fold, TYM 22-34\% of EL;

(5) small pharyngeal ostia present;

(6) TIL 1.9-2.0 times HAND;

(7) snout rounded to subovoid in dorsal view, slightly sloping in profile, canthus rostralis nearly straight in dorsal view, rounded in cross section, loreal region concave, flaring slightly at upper lip;

(8) upper eyelid granular, with 1-3 distinctly enlarged tubercles on each eyelid;

(9) choanae small, round, dentigerous processes of vomers small, sometimes barely visible or even not detectable, slightly oblique, ovoid, posterior and medial to choanae, each bearing 3-5 teeth when present;

(10) presence of vocal slits in male, vocal sac single, subgular;

(11) tongue cordiform;

(12) one unpigmented whitish nuptial pad located on the preaxial side of the thenar tubercle on each thumb in male, a second pad is sometimes present (on one thumb or on both) on the preaxial side of the first subarticular tubercle; 
(13) Finger I shorter than II, FI $75-83 \%$ of FII in males, $86 \%$ of FII in female;

(14) fingers basally webbed, with moderately developed lateral fringes, usually more conspicuously developed preaxially on Finger II;

(15) palmar tubercle V-shaped, often broken in three distinct tubercles;

(16) axillary tubercles (sensu Myers \& Donnelly 2001) absent;

(17) small ulnar tubercles present, in line;

(18) small tarsal tubercles present, 1-3 slightly enlarged calcar tubercles present;

(19) inner metatarsal tubercle oval, about 3-4 times the size of the round, projecting outer metatarsal tubercle;

(20) Toe V longer than III, extending to the distal edge of the distal tubercle on Toe IV when toes are adpressed;

(21) toes with lateral fringes, best developed preaxially on Toes II-IV, webbing basal between Toes II-V;

(22) discs broadly expanded, elliptical;

(23) in life, main dorsal colour pattern ranges from large, weakly visible, dark brown or grey-brown blotches to nearly uniformly brownish grey, ventral colouration ranges from whitish to grey or dark brown with series of tiny, dark brown punctuations and light grey flecking;

(24) in preservative, main dorsal colour pattern similar to when alive, but with the melanin more prominent, revealing large, indistinct blotches or more or less uniformly distributed medium brown colour, ventral colouration consists in a uniformly distributed series of tiny, warm brown punctuations on the chin, belly and undersurfaces of the legs, feet and toes;

(25) in life, anterior and lower posterior surfaces of thighs brown to dark brown with light grey flecking (brown with white flecking in preservative);

(26) in life, diffuse yellow or pale green wash (white in preservative) on groin and absence of flashy colour on axillary/pre-axillary region;

(27) in life, iris pale gold to bronze with fine black reticulations, a median horizontal brown to reddish brown bar, and a vertical streak running across the iris;

(28) advertisement call consists in a single note repeated at a rate of ca 11 calls $/ \mathrm{min}$ with a dominant frequency ranging from 2756 to $3101 \mathrm{~Hz}$;

(29) males call exclusively at dusk, usually upside down on mossy tree trunks of low diameter;

(30) known elevational distribution ca 600 to $1800 \mathrm{~m}$.

\section{Material examined}

Holotype

VENEZUELA: §ె, Bolívar State, foot of Mount Roraima, F.V. McConnell and J.J. Quelch leg., Aug.Oct. 1898 (BMNH 1947.2.16.92, formerly 99.3.25.19).

\section{Other material}

GUYANA: $2 \hat{\jmath} \hat{\sigma}, 1$ juvenile, Cuyuni-Mazaruni District, slopes of Maringma-tepui, Philippe J.R. Kok

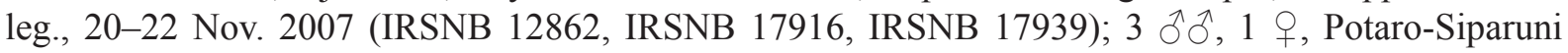
District, Kaieteur National Park, Philippe J.R. Kok leg., 26-28 Jun. 2006 (IRSNB 14471-74).

The holotype (BMNH 1947.2.16.92, formerly 99.3.25.19; Fig. 2) is an adult male with large vocal slits (gender of the holotype was not provided in the original description).

\section{Description of adult}

Measurements are provided in Table 2. Adult males 17.6-20.4 mm SVL $(n=5)$, distinctly smaller than adult female $27.9 \mathrm{~mm}$ SVL $(\mathrm{n}=1)$. Head slightly longer than wide, wider than body; HW 36-41\% of SVL; HL $37-45 \%$ of SVL; cranial crests absent. Snout longer than eye length (SL 102-133\% of EL), rounded to subovoid in dorsal view, slightly sloping in profile; canthus rostralis nearly straight in 


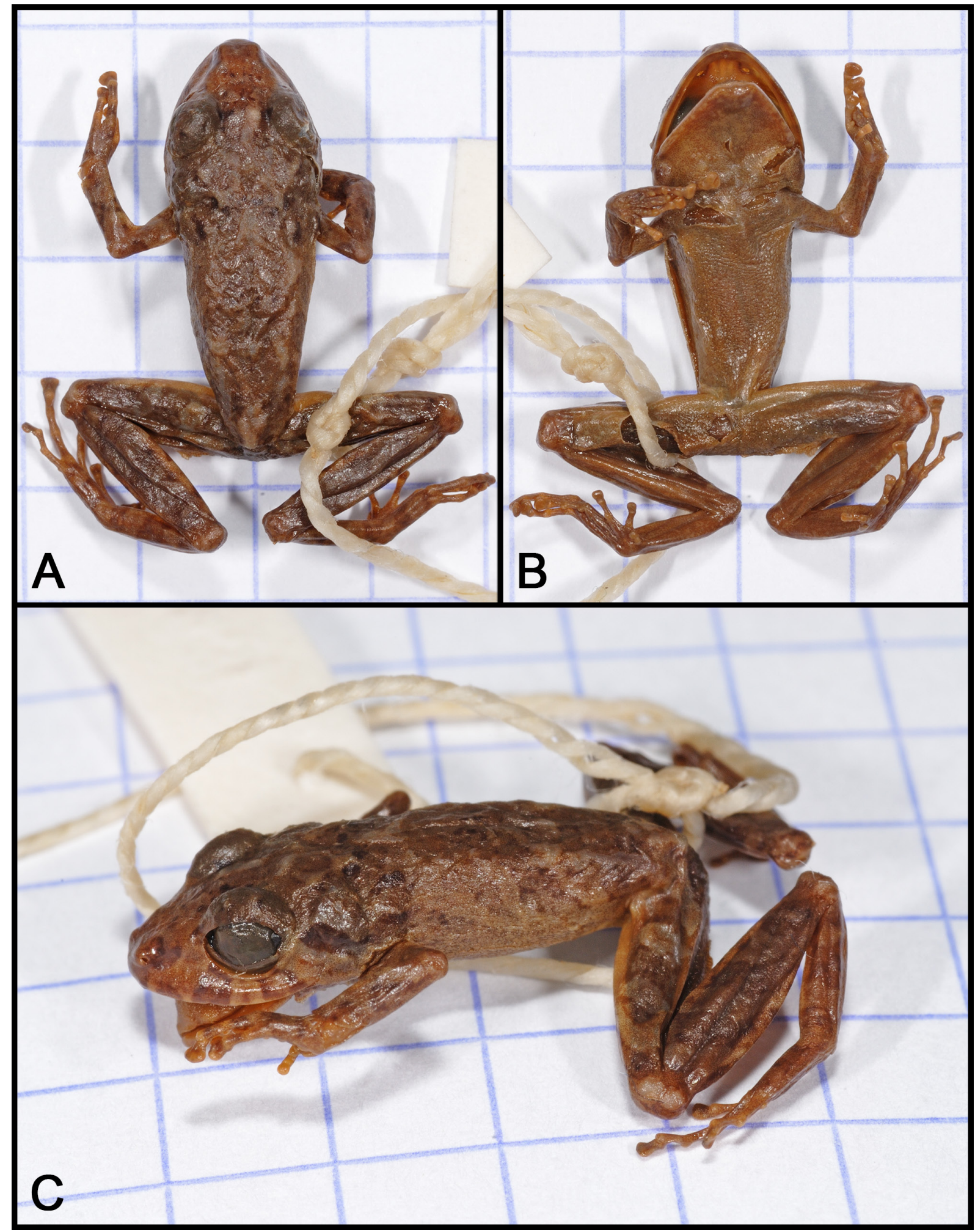

Fig. 2. Pristimantis marmoratus (Boulenger, 1900). Preserved adult $\widehat{\jmath}$, holotype (BMNH 1947.2.16.92). A. Dorsal view. B. Ventral view. C. Dorsolateral view. Grid squares $=5 \mathrm{~mm}$. Photographs by PJRK. 
Table 2. Measurements (in mm) of the holotype of Pristimantis marmoratus (Boulenger, 1900) and new specimens assigned to the nominal species (see text for details).

\begin{tabular}{|c|c|c|c|c|c|c|c|c|}
\hline Voucher & $\begin{array}{c}\text { Holotype, BMNH } \\
\text { 1947.2.16.92 } \\
\end{array}$ & $\begin{array}{l}\text { IRSNB } \\
14471 \\
\end{array}$ & $\begin{array}{l}\text { IRSNB } \\
14472 \\
\end{array}$ & $\begin{array}{l}\text { IRSNB } \\
14473 \\
\end{array}$ & $\begin{array}{l}\text { IRSNB } \\
17939 \\
\end{array}$ & $\begin{array}{c}\text { IRSNB } \\
12862 \\
\end{array}$ & $\begin{array}{l}\text { IRSNB } \\
14474 \\
\end{array}$ & $\begin{array}{c}\text { IRSNB } \\
17916 \\
\end{array}$ \\
\hline Gender & $\hat{0}$ & $\hat{0}$ & $\hat{\sigma}$ & $\hat{\sigma}$ & $\hat{0}$ & $\hat{0}$ & $q$ & Juvenile \\
\hline SVL & 17.9 & 19.4 & 19.0 & 17.6 & 20.4 & 20.2 & 27.9 & 11.3 \\
\hline HL & 7.1 & 8.2 & 7.0 & 7.9 & 8.2 & 8.9 & 11.0 & 5.1 \\
\hline HW & 6.4 & 7.0 & 7.1 & 6.8 & 7.7 & 8.3 & 10.2 & 4.5 \\
\hline SL & 3.0 & 2.4 & 3.3 & 3.3 & 3.6 & 3.4 & 4.6 & 1.8 \\
\hline $\mathbf{E N}$ & 1.9 & 2.4 & 3.1 & 2.4 & 2.6 & 2.6 & 3.0 & 1.3 \\
\hline IN & 1.7 & 1.8 & 1.8 & 1.8 & 2.0 & 1.7 & 2.5 & 0.6 \\
\hline EL & 2.7 & 3.6 & 2.8 & 2.8 & 3.5 & 3.4 & 3.5 & 1.9 \\
\hline IO & 2.3 & 2.1 & 2.5 & 1.9 & 2.3 & 2.1 & 2.6 & 1.5 \\
\hline TYM & 0.7 & 1.1 & 0.7 & 0.7 & 0.7 & 0.9 & 1.3 & 0.4 \\
\hline HAND & 4.8 & 5.7 & 5.7 & 5.3 & 5.6 & 6.1 & 7.4 & 2.7 \\
\hline WFD & 0.9 & 1.1 & 1.1 & 1.0 & 1.2 & 1.1 & 1.5 & 0.6 \\
\hline FL & 7.1 & 8.4 & 8.3 & 7.6 & 8.2 & 10.1 & 9.0 & 4.3 \\
\hline WTD & 0.8 & 1.1 & 1.0 & 1.1 & 1.3 & 1.0 & 1.3 & 0.6 \\
\hline TIL & 9.7 & 10.8 & 10.9 & 10.2 & 11.0 & 11.9 & 14.0 & 5.9 \\
\hline
\end{tabular}

dorsal view, rounded in cross section, loreal region concave, flaring slightly at upper lip; EN 80-110\% of EL. Nares protuberant, directed posterolaterally, visible in front, dorsal and usually ventral views. Widest upper eyelid width equal or subequal to interorbital distance. Upper eyelid granular, with 1-3 distinctly enlarged tubercles on each eyelid. Tympanum present, tympanic membrane not or only poorly differentiated, tympanic annulus only partially visible externally, obscured by supratympanic fold, TYM $22-34 \%$ of EL; small pharyngeal ostia present. Choanae small, round, not concealed by palatal shelf of maxillary arch; dentigerous processes of vomers small, sometimes barely visible or even not detectable (e.g., in IRSNB 14473 on both sides, in IRSNB 17939 on left side, in IRSNB 14471 on right side), slightly oblique, ovoid, posterior and medial to choanae, each bearing 3-5 teeth when present. Tongue cordiform, slightly longer than wide, posterior half free. Vocal slits present in male, vocal sac single, subgular.

Dorsal skin texture fairly variable (probably depending on activity, as observed in several species of the genus; see for example Guayasamin et al. 2015), from granular to pustulate, including on head, usually with distinctly enlarged tubercles (dorsal skin less pustulate in female); well-developed oblique scapular ridges in males (less prominent in female); middorsal raphe not, or barely, detectable; supratympanic fold conspicuous in life, slightly arched, originating at posterior corner of eye, failing to reach shoulder; large post-rictal tubercles present; a weak dermal fold often present along upper flank; flanks granular. Throat surface smooth; upper chest smooth; weak thoracic fold; belly skin granular, those granules not as closely set as in so-called areolate skin (sensu Duellman \& Lehr 2009), sometimes becoming smooth in preservative; weak discoidal fold anterior to groin; posteroventral thigh and cloacal region areolate; cloacal sheath absent.

Hand length $26-30 \%$ of SVL. Finger I $75-83 \%$ of FII in males, $86 \%$ of FII in female. Relative length of fingers III > IV > II > I; adpressed Finger I fails to reach proximal edge of digital pad of Finger II; adpressed Finger IV reaches beyond distal subarticular tubercle. One unpigmented whitish (translucent when wet) nuptial pad located on preaxial side of thenar tubercle on each thumb in male, a second 
pad is sometimes present (on one thumb or on both) on preaxial side of first subarticular tubercle. Fingers basally webbed, with moderately developed lateral fringes, usually more conspicuously developed preaxially on Finger II. Finger discs broadly elliptical, broader than long, circumferential groove conspicuous; disc on Finger III ca three times as wide as distal end of adjacent phalanx. Palmar tubercle V-shaped, usually pigmented, often broken in three distinct small tubercles; thenar tubercle large, ovoid, protuberant; supernumerary tubercles few, large, subequal to subarticular tubercles, round and protuberant: subarticular tubercles large, round and protuberant, one each on FI and FII, two each on FII and FIV (Fig. 3). Ulnar tubercles small, in line. Axillary tubercles absent.

Hind limbs moderate in length, heels slightly overlap when held at right angles to sagittal plane; TIL $50-59 \%$ of SVL; FL $32 \%$ of SVL in female, $40-50 \%$ of SVL in males. Relative length of toes IV $>$ V > III > II > I; tip of Toe V extends to distal edge of distal tubercle on Toe IV when toes are adpressed. Lateral fringes on all toes, best developed preaxially on Toes II-IV; webbing basal between Toes II-V. Toe discs subequal to finger discs, WTD/WFD 0.9; toe discs broadly expanded, elliptical, broader than long, circumferential groove conspicuous. Inner metatarsal tubercle elongate, oval, about 3-4 times size of round, projecting outer metatarsal tubercle; subarticular tubercles round, large and protuberant; supernumerary plantar tubercles small, low and round, increasing in size distally (Fig. 3). One to three slightly enlarged calcar tubercles present; outer tarsal tubercles few, low, barely detectable in preservative; inner tarsal fold short, straight to slightly curved.

\section{Colour in life}

The dorsal pattern of living specimens ranges from large, weakly visible, dark brown or grey-brown blotches to nearly uniformly brownish grey. Dorsolaterally, the pair of oblique scapular ridges is light grey on top and edged with black pigment, running from the level of the posterior of the eye to the level of the armpit. One specimen (IRSNB 14473) has distinct beige oblique lateral stripes running from tip of snout (where they fuse) to groin. Top of the forearm with a single, medial, dark brown band about onethird to one-half the width of the forearm; top of the thigh with three wide dark brown bands alternating with three light grey or reddish brown bands, all continuing onto the top of the tarsus. Diffuse yellow or paler green wash on groin. A dark blotch runs from over the ear to the angle of the mouth and two wide, dark vertical patches span from the eye to the upper lip (Fig. 4). Canthus rostralis not set off by colour from the snout or upper lip as in some other Pristimantis (e.g., in P. pulvinatus, see Fig. 4). Iris pale gold to bronze with fine black reticulations, a median horizontal brown to reddish brown bar, and a vertical streak running across the iris (Fig. 4). The ventral pattern is fairly variable and may change depending on light intensity, varying from whitish to grey or dark brown with series of tiny, dark brown punctuations and light grey flecking, the latter mostly on the belly. Skin on belly is translucent with some organs visible through it. Anterior and lower posterior surfaces of thighs are brown to dark brown with light grey flecking. Palms and soles are grey to dark brown.

\section{Colour in preservative}

Dorsal colour in specimens after ca 10 years in preservative is similar to when alive, but with the melanin more prominent, revealing the large, indistinct blotches on some specimens and a more or less uniformly distributed medium brown colour on others. Relatively distinct light areas in the shape of a V extend backward from the posterior of the orbit with the apex of the $\mathrm{V}$ terminating at the scapular ridges at the level of the insertion of the forelimbs; margins of the light $\mathrm{V}$ patch are usually edged with black pigment. The dark transverse bands on the forearm and legs described for living frogs are much more pronounced in preserved specimens. Anterior and lower posterior surfaces of thighs are light brown with white flecking. The diffuse yellow/pale green wash on the groin present in life becomes immaculate white in preservative. Ventral colouration is a uniformly distributed series of tiny, warm brown punctuations on the chin, belly, and undersurfaces of the legs, feet, and toes (Fig. 5). The preserved holotype ( $>115$ years 


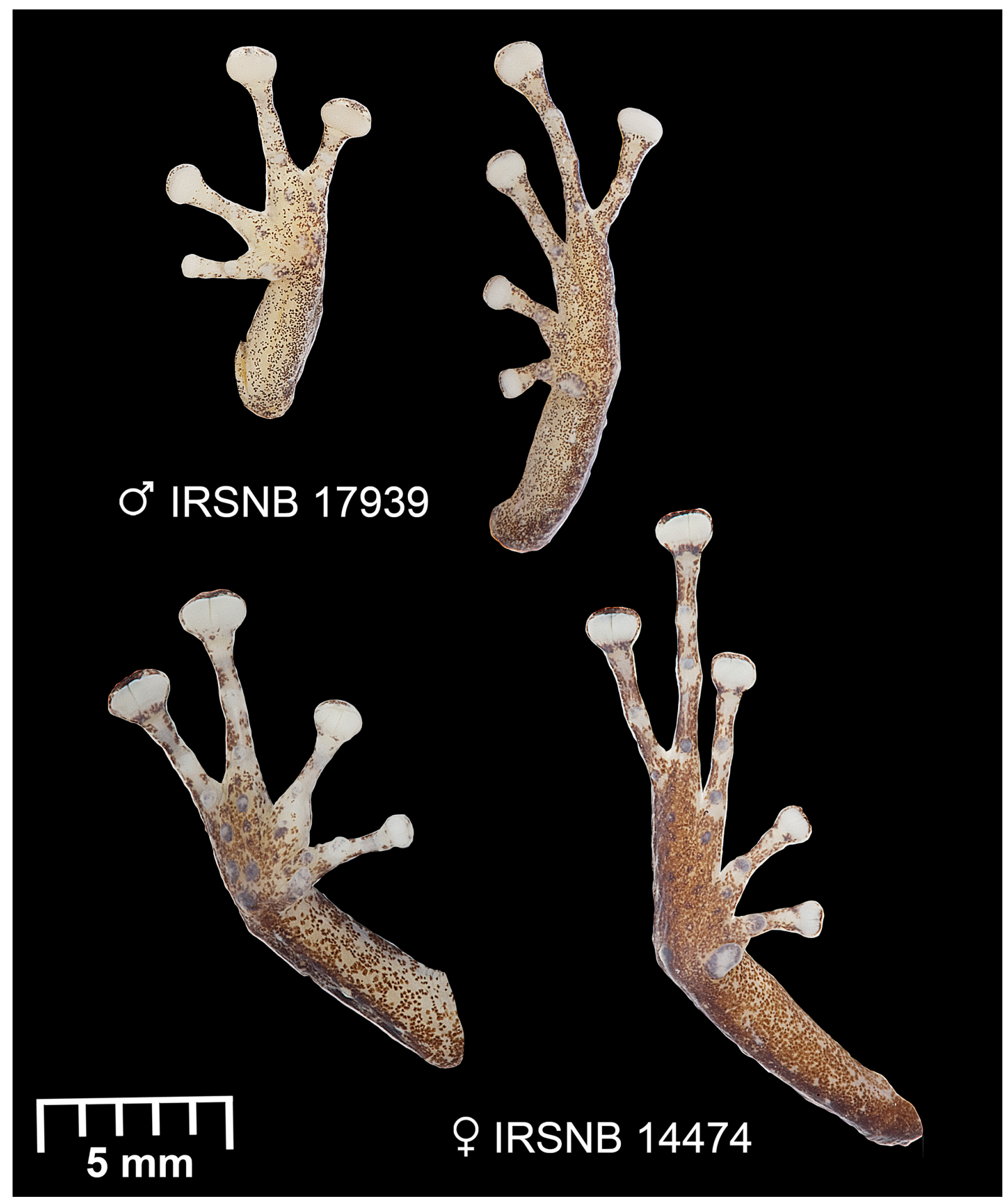

Fig. 3. Pristimantis marmoratus (Boulenger, 1900). Ventral view of left hand and left foot of a male (top), and ventral view of right hand and right foot of a female (below), both from Kaieteur National Park, Guyana. Photographs by PJRK. 


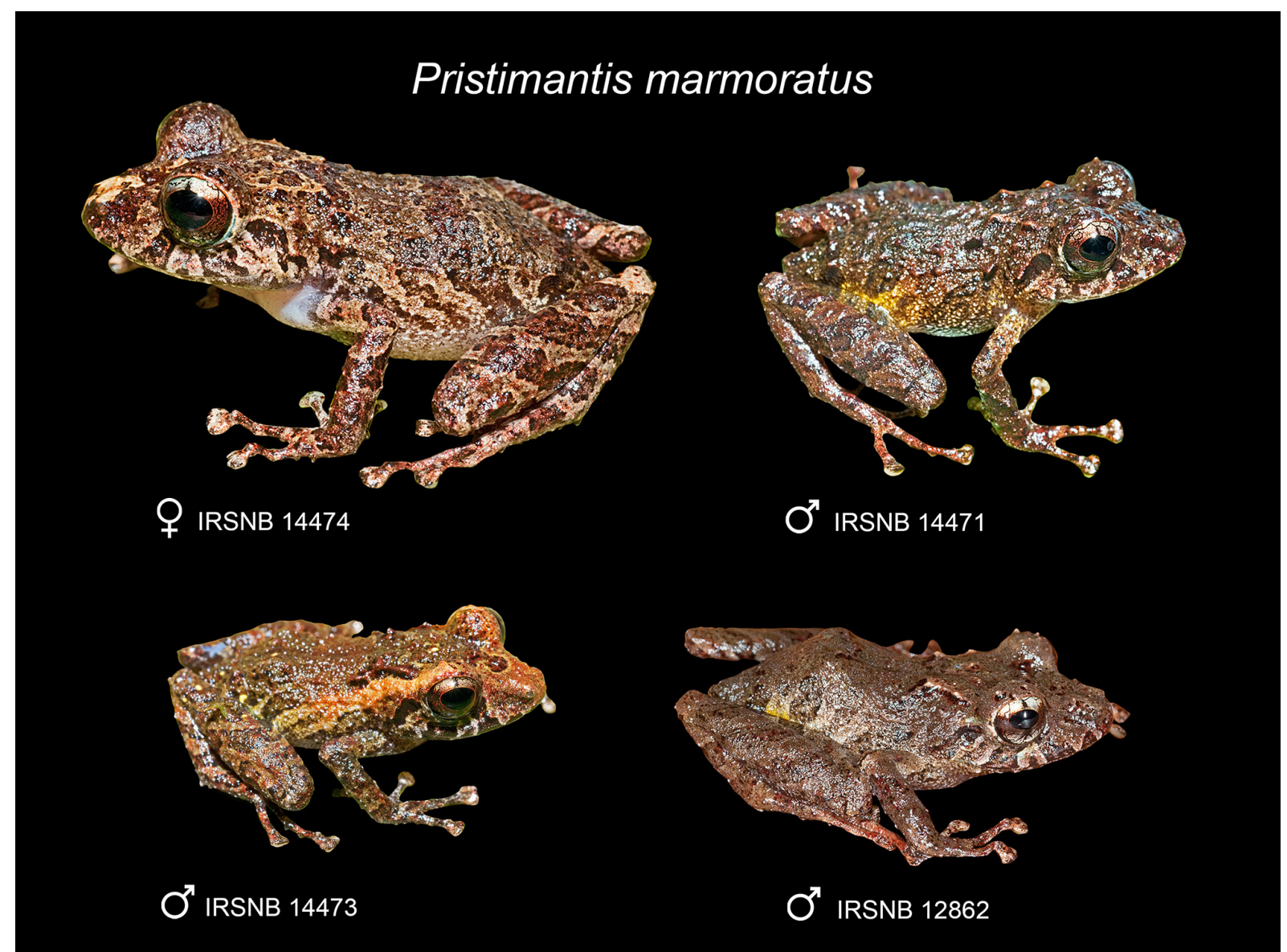

\section{Pristimantis pulvinatus}
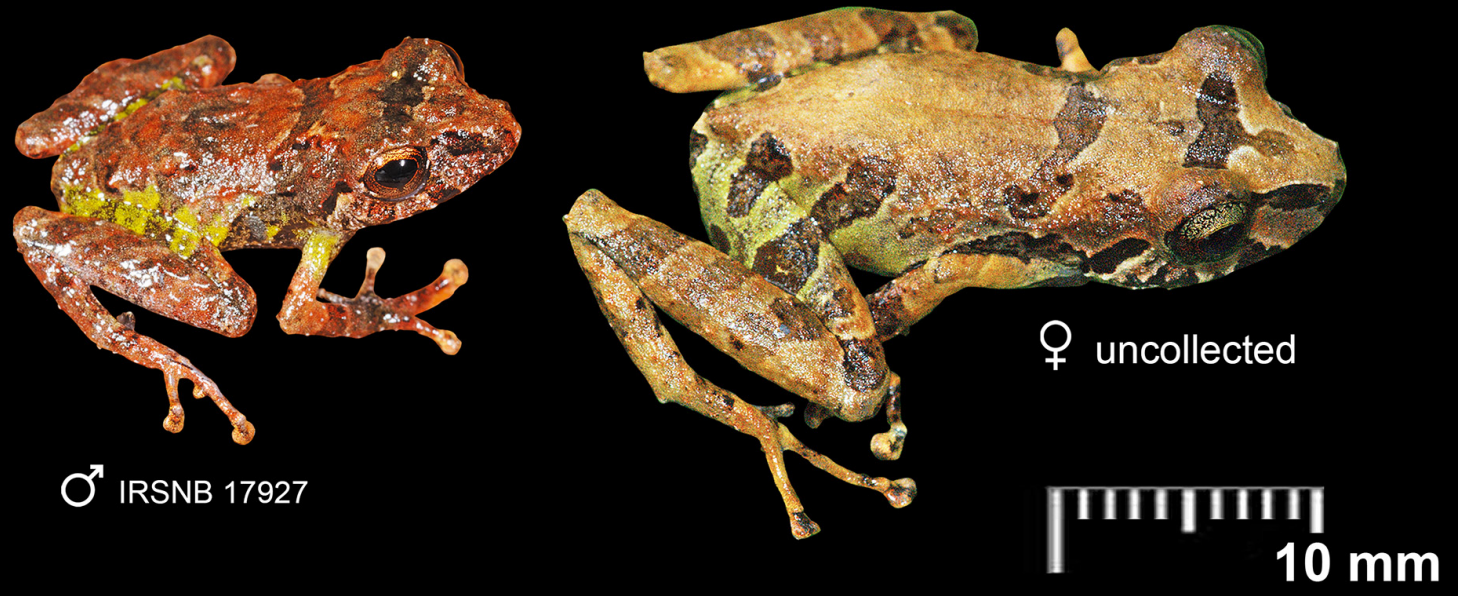

Fig. 4. Pristimantis marmoratus (Boulenger, 1900) (four individuals at the top) and P. pulvinatus (Rivero, 1968) (two individuals below). Intraspecific variation in dorsal colour pattern and sexual dimorphism in living specimens. Note: the subtle hint of green visible on the lower body and legs of some specimens of $P$. marmoratus is due to a reflection of the substrate (green leaf). Photographs by PJRK, except the uncollected $P$. pulvinatus, which is by CBA. 
in preservative, Fig. 2) has a similar colour pattern as the other specimens examined, except that its skin has turned completely brown dorsally and ventrally, and some markings have faded.

\section{Colour in juvenile}

The colour pattern of one live juvenile (Fig. 6D) was similar to that of the adults, except that a wide band of black pigment wrapped around the anterior one-third of the body from the middle of the belly to between the eyes and the top the orbits, including the forearms and feet. Another blotch of black pigment covered one-fifth of the posterior of the back and cloaca as well as on the opposing parts of the heels and tips of the knees. Light brown colour with a faint stippling of tiny dark brown dots formed a dorsal saddle between the darkly pigmented areas and coloured the entire snout, top of the hind limbs, a roundish blotch over the ear, and on top of the two small warty scapular ridges. As in the adults, three medium brown, transverse crossbands are evident on top of all three segments of the hind limbs, continuing from the sides of the body. Two prominent, black-pigment-fringed, medium brown dorsoventral streaks run from the bottom of each orbit to the upper lip. As in adults, the iris is bronze with fine black reticulations, a median horizontal reddish brown bar and a vertical streak running across the iris. The ventral parts of the juvenile were completely black covered by light grey and light greenish brown flecks.

\section{Sexual dimorphism}

Sexual dimorphism is evident in size (Figs 4-5), with the only known adult female being much larger than adult males (max. $20.4 \mathrm{~mm}$ SVL in males vs $27.9 \mathrm{~mm} \mathrm{SVL}$ in female), and by the presence of 1-2 whitish nuptial pads in males. Since only one female is known, possible sexually dimorphic characters are hard to evaluate, but we nevertheless note differences in the dorsal skin texture (less tuberculate in the female, with less prominent oblique scapular ridges; Figs 4-5). No evident sexual dichromatism is detected, although the only known female has a large whitish unpigmented blotch on the lower throat and upper chest, which is absent in males (Fig. 5). Compared to SVL, hands and tibia are slightly longer in males than in the only known female (HAND $27-30 \%$ vs $26 \%$ of SVL in female; TIL $54-59 \%$ vs $50 \%$ of SVL in female), and feet are longer in males than in the only known female (FL 40-50\% vs 32\% of SVL in female). No additional significant difference was detected in other size ratios.

\section{Comparison with other species from the Guiana Shield}

The combination of FI $<$ II, SVL $\leq 20.4$ in males, presence of vocal slits in males, granular/pustulate dorsal skin with well-developed scapular ridges, basal webbing between fingers, fringes on fingers and toes, crossed iris, diffuse yellow or pale green wash on groin, absence of flashy colour on axillary/preaxillary region, and absence of conspicuous canthal stripe immediately distinguish Pristimantis marmoratus from all described congeners reported from the Guiana Shield, lowlands included.

More specifically compared to the 23 described species of Pristimantis currently reported from the Guiana Shield uplands and highlands (i.e., between ca 400 and $2900 \mathrm{~m}$ elevation), Pristimantis marmoratus is immediately distinguished from P. abakapa Rojas-Runjaic, Salerno, Señaris \& Pauly, 2013, P. aureoventris Kok, Means \& Bossuyt, 2011, P. auricarens (Myers \& Donnelly, 2008), P. cantitans (Myers \& Donnelly, 1996), P. dendrobatoides Means \& Savage, 2007, P. imthurni Kok, 2013, P. jamescameroni Kok, 2013, P. jester Means \& Savage, 2007, P. marahuaka (Fuentes-Ramos \& Barrio-Amorós, 2004), P. muchimuk Barrio-Amorós, Mesa, Brewer-Carías \& McDiarmid, 2010, P. saltissimus Means \& Savage, 2007, P. yaviensis (Myers \& Donnelly, 1996), and P. yuruaniensis Rödder \& Jungfer, 2008, by the presence of large vocal slits in males (absent in the aforementioned species); from P. guaiquinimensis (Schlüter \& Rödder, 2007) (male unknown, see Kok \& Barrio-Amorós 2013) mainly in having granular/tuberculate skin (smooth to finely granular in P. guaiquinimensis), fringes on fingers and toes (absent in P. guaiquinimensis), basal webbing between most fingers and toes 


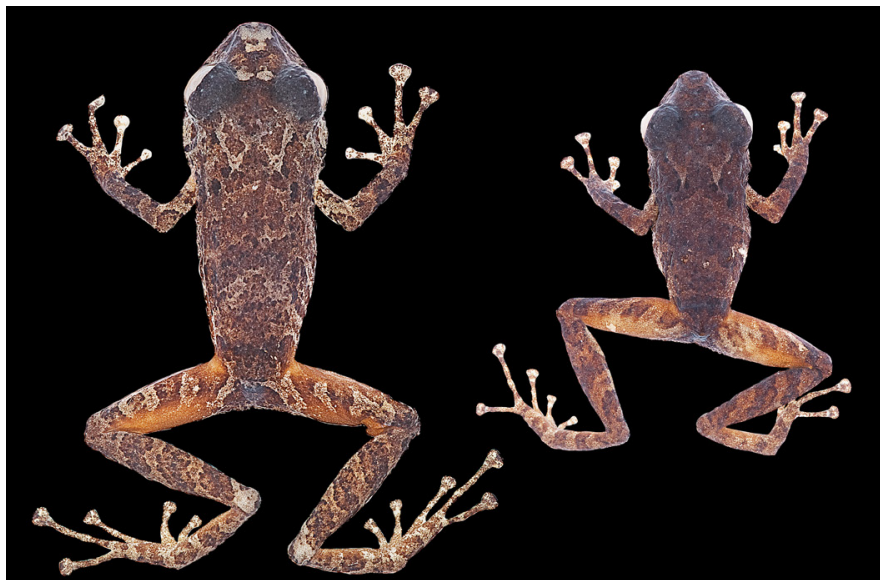

ᄋ IRSNB 14474
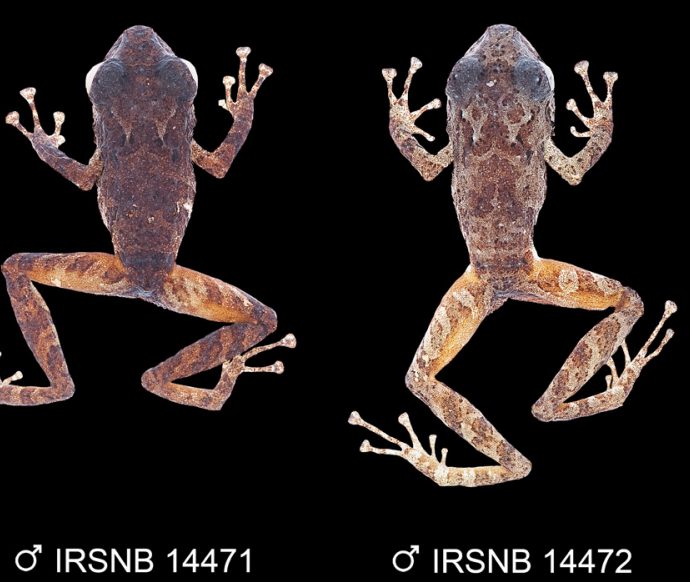

O' IRSNB 14472
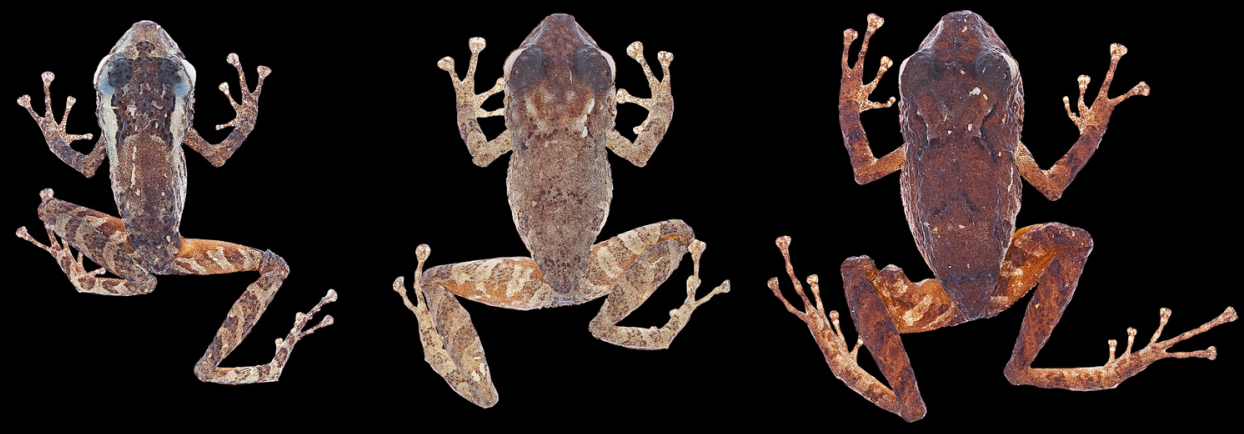

O' IRSNB 14473

ơ IRSNB 17939

O’ IRSNB 12862
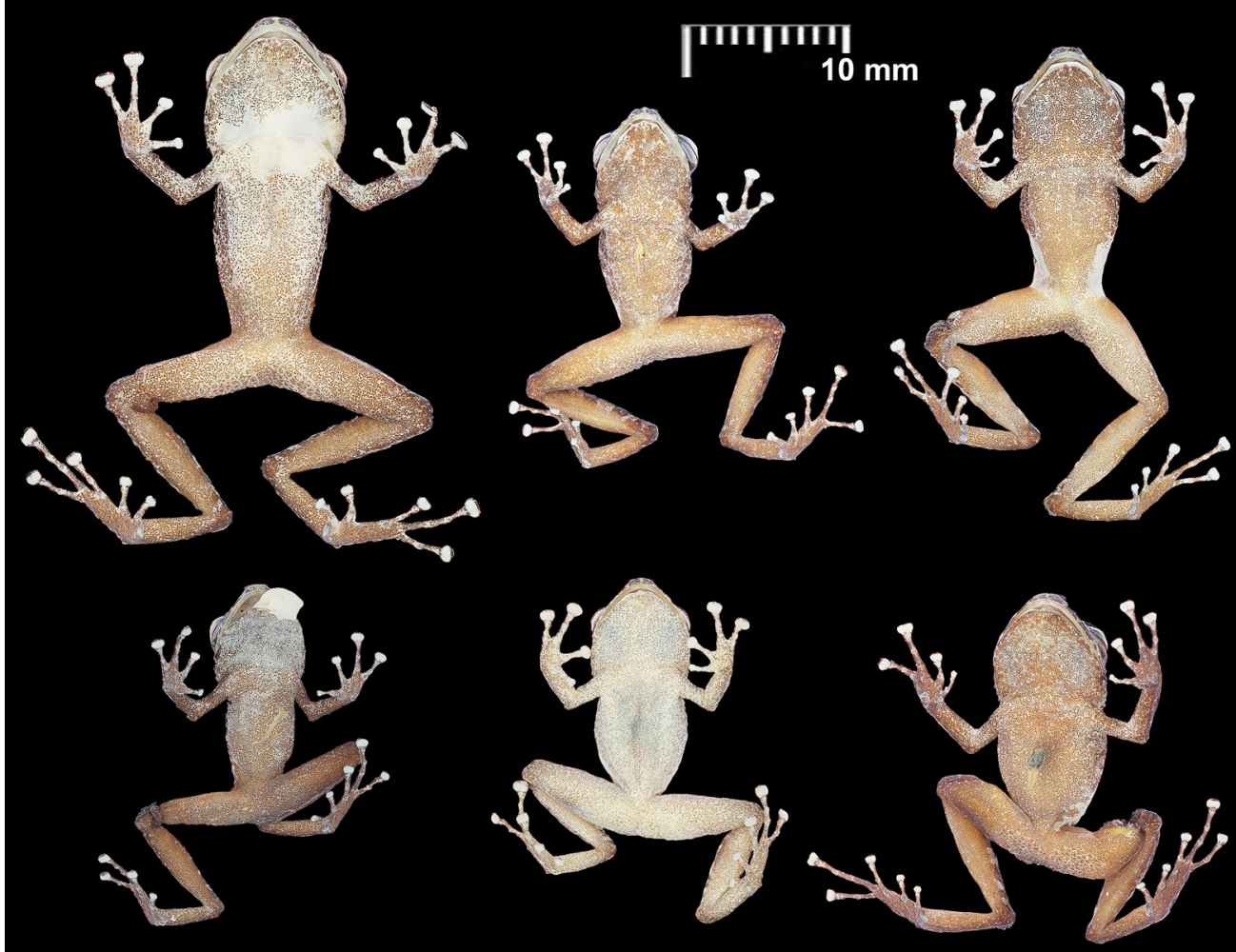

Fig. 5. Pristimantis marmoratus (Boulenger, 1900). Intraspecific variation in dorsal (top) and ventral (below) colour patterns in preserved specimens. Photographs by PJRK. 
(absent), and smaller SVL in female (27.9 mm in P. marmoratus vs 32.4-34.7 in P. guaiquinimensis); and from P. vilarsi (Melin, 1941) and P. zeuctotylus (Lynch \& Hoogmoed, 1977) mainly in having FI $<$ II (FI $>$ II in P. vilarsi and P. zeuctotylus). The remainder seven described Pristimantis species found in the Guiana Shield uplands and highlands also have vocal slits in males. Compared to those, P. marmoratus is mainly distinguished from P. avius (Myers \& Donnelly, 1997) (endemic to the Sierra Tapirapecó, Amazonas State, Venezuela) by its smaller size (17.6-20.4 mm SVL in males, $27.9 \mathrm{~mm}$ SVL in female in P. marmoratus vs $20.0-24.0 \mathrm{~mm}$ SVL in males, $31.0-33.0 \mathrm{~mm} \mathrm{SVL}$ in females in P. avius), absence of yellow or orange colouring on ventral surface (present in $P$. avius), presence of a vertical streak running across the iris (absent in P. avius), and presence of fringes on fingers and toes (absent in P. avius); from P. cantitans (Myers \& Donnelly, 1997) (endemic to Cerro Yaví, Amazonas State, Venezuela) mainly by its much smaller size (17.6-20.4 mm SVL in males, $27.9 \mathrm{~mm} \mathrm{SVL}$ in female in P. marmoratus vs 24.9-34.5 mm SVL in males, 31.9-44.7 mm SVL in females in P. cantitans), presence of a vertical streak running across the iris (absent in P. cantitans), diffuse yellowish/pale green colouration on groin and absence of colourful marking on posterior thigh surface ( $P$. cantitans has the posterior thigh surface blackish with yellow flecking, and with a rose wash in the groin, anterior thigh, and concealed

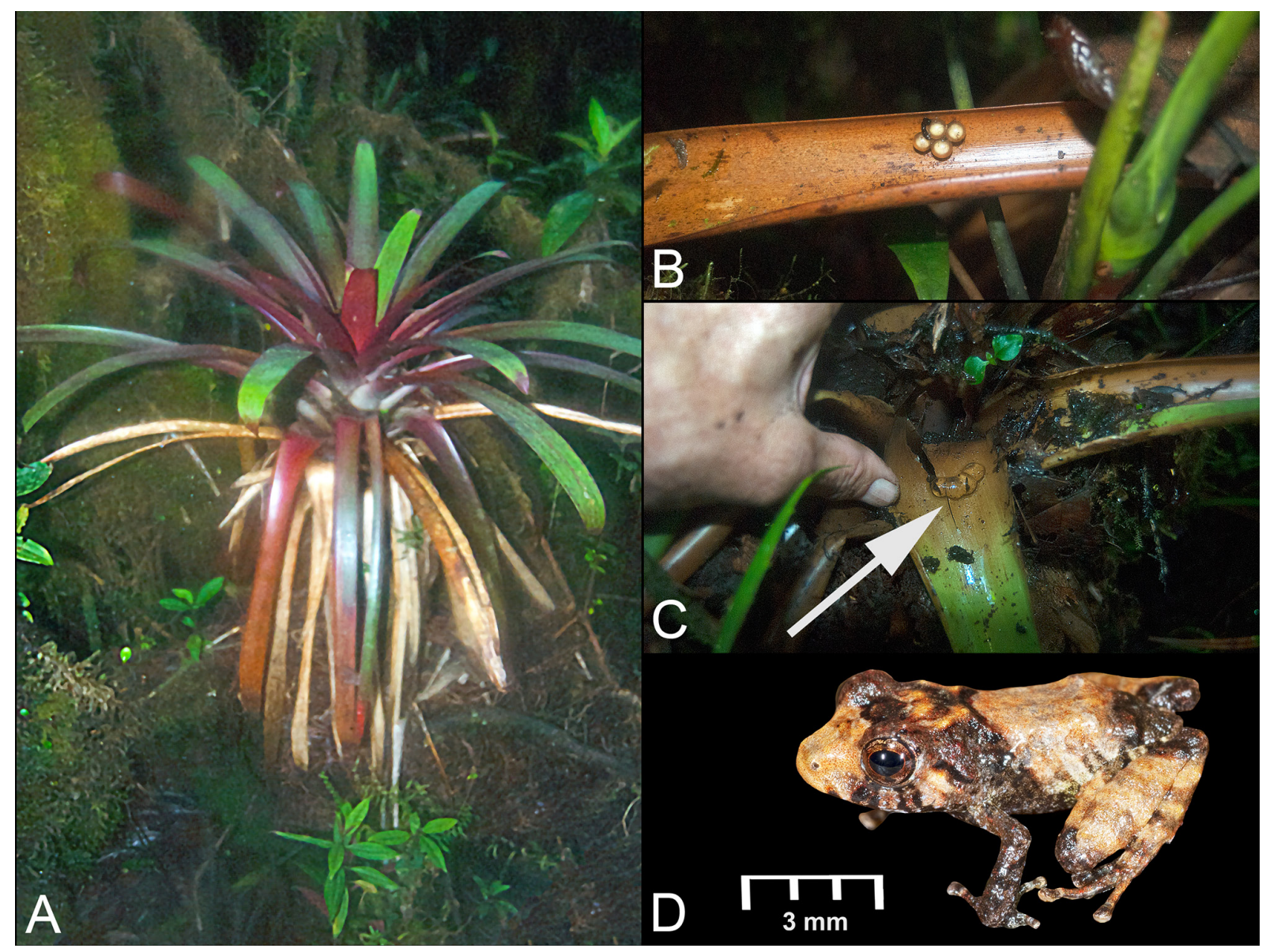

Fig. 6. A. Guzmania cf. sphaeroidea (André) André ex Mez, an arboreal bromeliad species used as egg deposition site by Pristimantis marmoratus (Boulenger, 1900) in the Wokomung Massif. B. Egg clutch of Pristimantis marmoratus deposited on a leaf of the arboreal bromeliad Guzmania cf. sphaeroidea in the Wokomung Massif. C. Egg clutch of Anomaloglossus beebei (Noble, 1923) (white arrow) deposited in the phytotelmata of the same plant as in B. D. Dorsolateral view of IRSNB 17916, $11.3 \mathrm{~mm}$ SVL, a juvenile of $P$. marmoratus collected on the slopes of Maringma-tepui, Guyana. Photographs A-C by DBM, D by PJRK. 
portion of the shank); from P. espedeus Fouquet, Martinez, Courtois, Dewynter, Pineau, Gaucher, Blanc, Marty \& Kok, 2013 (reported only between 200 and 700 m elevation in French Guiana) mainly by its smaller size (17.6-20.4 mm SVL in males, $27.9 \mathrm{~mm}$ SVL in female in P. marmoratus vs 20.7-24.8 mm SVL in males, $29.4 \mathrm{~mm} \mathrm{SVL}$ in female in $P$. espedeus), diffuse yellowish/pale green colouration on groin (P. espedeus has the anterior surface of thighs and groin reddish), no sharp demarcation between dorsal and flank colours (present in P. espedeus) and presence of a vertical streak running across the iris (absent in P. espedeus); from P. memorans (Myers \& Donnelly, 1997) (reported only from the Sierra Tapirapecó in Amazonas State, Venezuela, and adjacent Amazonas State in Brazil) by the presence of fringes on fingers and toes (absent in P. memorans), presence of a vertical streak running across the iris (absent in P. memorans) and in having a diffuse yellowish/pale green colouration on groin (absent in P. memorans); from $P$. pruinatus (Myers \& Donnelly, 1996) (known only from Cerro Yaví, Amazonas State, Venezuela) by the presence of fringes on fingers and toes (absent in P. pruinatus), in having the tip of Toe $\mathrm{V}$ extending to the distal edge of the distal tubercle on Toe IV when toes are adpressed (extends only midway to proximal edge of ultimate subarticular tubercle on Toe IV in P. pruinatus), presence of a vertical streak running across the iris (absent in P. pruinatus), absence of dark orange brown on ventral surface and anterior and posterior thigh surfaces (present in P. pruinatus), and discernible dorsal colour pattern in preservative (dorsum patternless, blackish grey in P. pruinatus); from P. pulvinatus (Rivero, 1968), reported from the uplands of the Gran Sabana region of south-eastern Venezuela to adjacent western Guyana, therefore sympatric with $P$. marmoratus, mainly in having a vertical streak running across the iris (upper part of streak absent in P. pulvinatus, see Fig. 4), prominent scapular ridges in males (absent or usually fainter in P. pulvinatus, see Fig. 4), canthus rostralis not conspicuously marked (dark canthal stripe present in P. pulvinatus, see Fig. 4), absence of broad, conspicuous, dorsal dark bands between eyes and between axilla (usually present in P. pulvinatus, see Fig. 4 and Rivero 1968: fig. 1), and in lacking any flashy colour on axillary/pre-axillary region (present, green in P. pulvinatus, see Fig. 4); and from P. sarisarinama Barrio-Amorós \& Brewer-Carías, 2008 (endemic to Sarisariñamatepui, Bolívar State, Venezuela) mainly by the presence of fringes on fingers and toes (absent in $P$. sarisarinama), in having a vertical streak running across the iris (absent in P. sarisarinama) and in having a diffuse yellowish/pale green colouration on groin (absent in P. sarisarinama).

\section{Advertisement call}

\section{Temporal structure}

The advertisement call of Pristimantis marmoratus consists of a single, unpulsed (tonal) note repeated at a rate of $11.25-11.87$ calls $/ \mathrm{min}$. Mean call duration is $0.0184 \pm 0.002 \mathrm{~s}(0.016-0.023 \mathrm{~s})$. The intercall silent interval is relatively uniform and has a mean of $6.011 \pm 0.9 \mathrm{~s}$ and a range of 5.023-7.958 s (Figs 7-8).

\section{Spectral structure}

Four to five harmonics are developed, with the dominant frequency located in the first (fundamental) harmonic (mean: $3047 \pm 121 \mathrm{~Hz}$; range: 2756-3101 Hz) (Figs 7-8). Calls show a downward followed by a slightly upward frequency modulation (Fig. 8).

\section{Comparison with other Pristimantis calls in the Guiana Shield uplands and highlands}

To the best of our knowledge, only three uplands/highlands Pristimantis species for which documented calls are known produce a single note per call: P. aureoventris from above $2200 \mathrm{~m}$ elevation on Wei-Assiputepui and on the highest slopes of Mt. Roraima (Kok et al. 2011), P. muchimuk Barrio-Amorós, Mesa, Brewer-Carías \& McDiarmid, 2010 from above 2300 m elevation on Churí-tepui, and P. yuruaniensis Rödder \& Jungfer, 2008 from above $2300 \mathrm{~m}$ on Yuruaní-tepui. The call of $P$. aureoventris mainly differs in having a lower dominant frequency $(2180-2430 \mathrm{~Hz}$ vs $2756-3101 \mathrm{~Hz}$ in $P$. marmoratus $)$, and a higher call rate $(18$ calls $/ \mathrm{min}$ vs ca 11 calls $/$ min in $P$. marmoratus $)$. The call of $P$. muchimuk is longer $(0.027-$ $0.062 \mathrm{~s}$ vs $0.016-0.023 \mathrm{~s}$ in $P$. marmoratus) and emitted at a much faster pace (> $100 \mathrm{calls} / \mathrm{min}$ vs ca 11 
calls / min in P. marmoratus). The call of $P$. yuruaniensis is longer $(0.093-0.139 \mathrm{~s}$ vs $0.016-0.023 \mathrm{~s}$ in P. marmoratus) and the dominant frequency is at $1980 \mathrm{~Hz}(2756-3101 \mathrm{~Hz}$ in P. marmoratus).

Interestingly, the call of Pristimantis marmoratus is extremely similar to the call of P. inguinalis (Parker, 1940), a species known from the lowlands of the eastern Guiana Shield, east of the Essequibo River. Both species have an unpulsed single note call with a dominant frequency within the same range. Based on our analysis of a call of P. inguinalis provided in Marty \& Gaucher (1999) and partial data from Fouquet et al. (2013), the only differences found are (1) a slightly longer call length in $P$. inguinalis (0.023-0.032 s vs $0.016-0.023 \mathrm{~s}$ in P. marmoratus); (2) a slightly higher call rate in P. inguinalis (17.91 calls / min vs $11.25-11.87$ calls / $\mathrm{min}$ in P. marmoratus); and (3) a slightly shorter inter-call silent interval
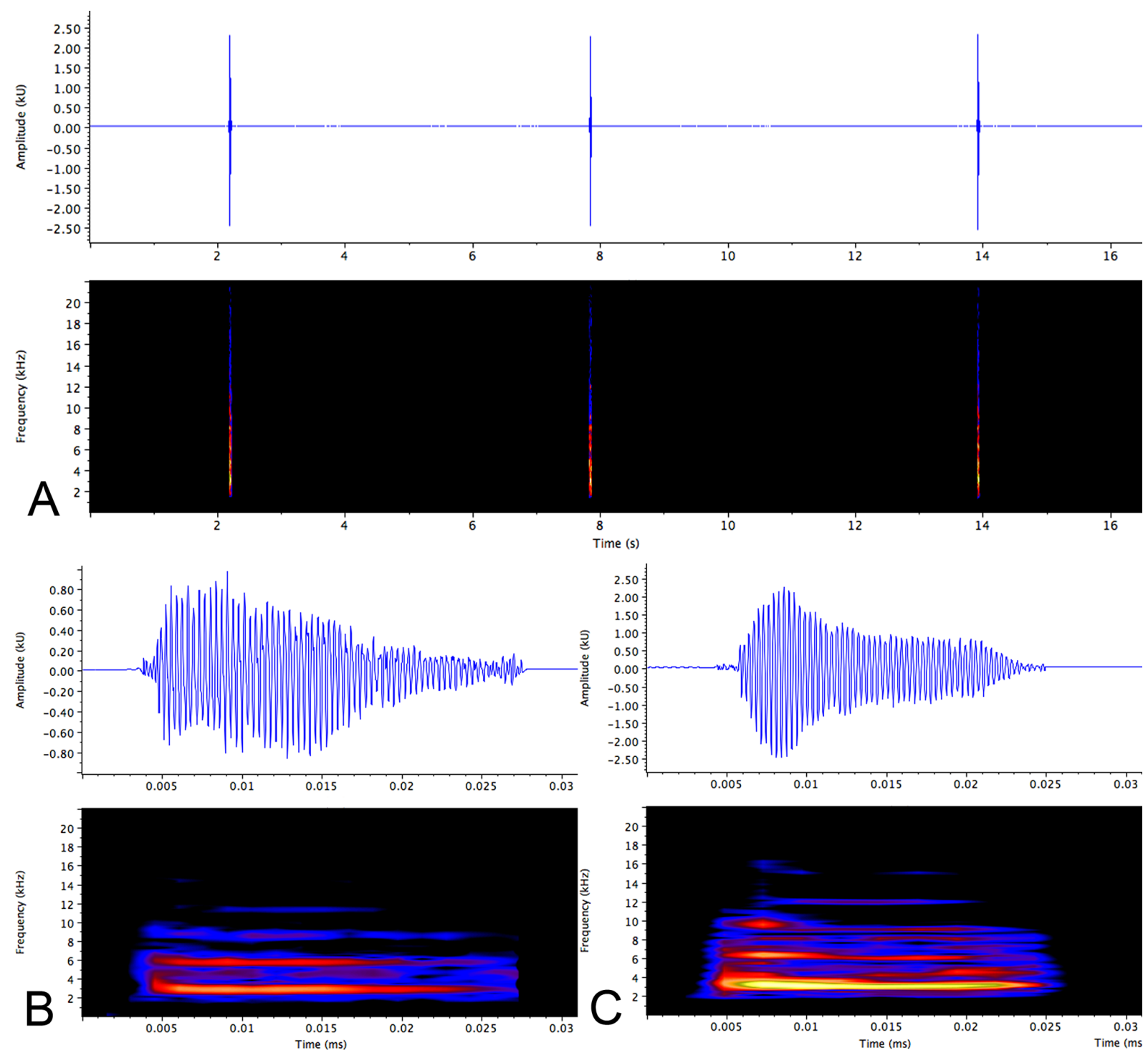

Fig. 7. Vocalization of Pristimantis marmoratus (Boulenger, 1900); oscillograms and spectrograms obtained using Raven v. 1.4. A. Oscillogram (top) and spectrogram (below) of three calls of IRSNB 14472 from Kaieteur National Park, Guyana (ca 16 s recording). B. Expanded oscillogram (top) and spectrogram (below) of one call of IRSNB 14471 from Kaieteur National Park, Guyana. C. Expanded oscillogram (top) and spectrogram (below) of one call of IRSNB 14472 from Kaieteur National Park, Guyana. Calls recorded at a temperature of $24^{\circ} \mathrm{C}$. 
in P. inguinalis (3.16-3.85 s vs 5.02-7.96 s in P. marmoratus). See Discussion for further comments about distribution and phylogenetic relationships; see also fig. 6 in Fouquet et al. (2013) for comparison.

\section{Distribution}

Pristimantis marmoratus is currently known only from - west to east - the La Escalera region in Venezuela, the southern base of Mount Roraima in Venezuela (type locality) and the north-eastern base of Mount Roraima in Guyana (Double Drop Falls), the slopes of Maringma-tepui along the border between Guyana and Brazil, Mount Ayanganna in Guyana (MacCulloch \& Lathrop 2009), the Wokomung Massif in Guyana and Kaieteur National Park in Guyana (Fig. 1). The species occurs between ca 600 and $1800 \mathrm{~m}$ above sea level, and is probably restricted to the pristine submontane and montane rainforests of the Pantepui uplands and highlands, east of the Gran Sabana, i.e., the Eastern Pantepui District of

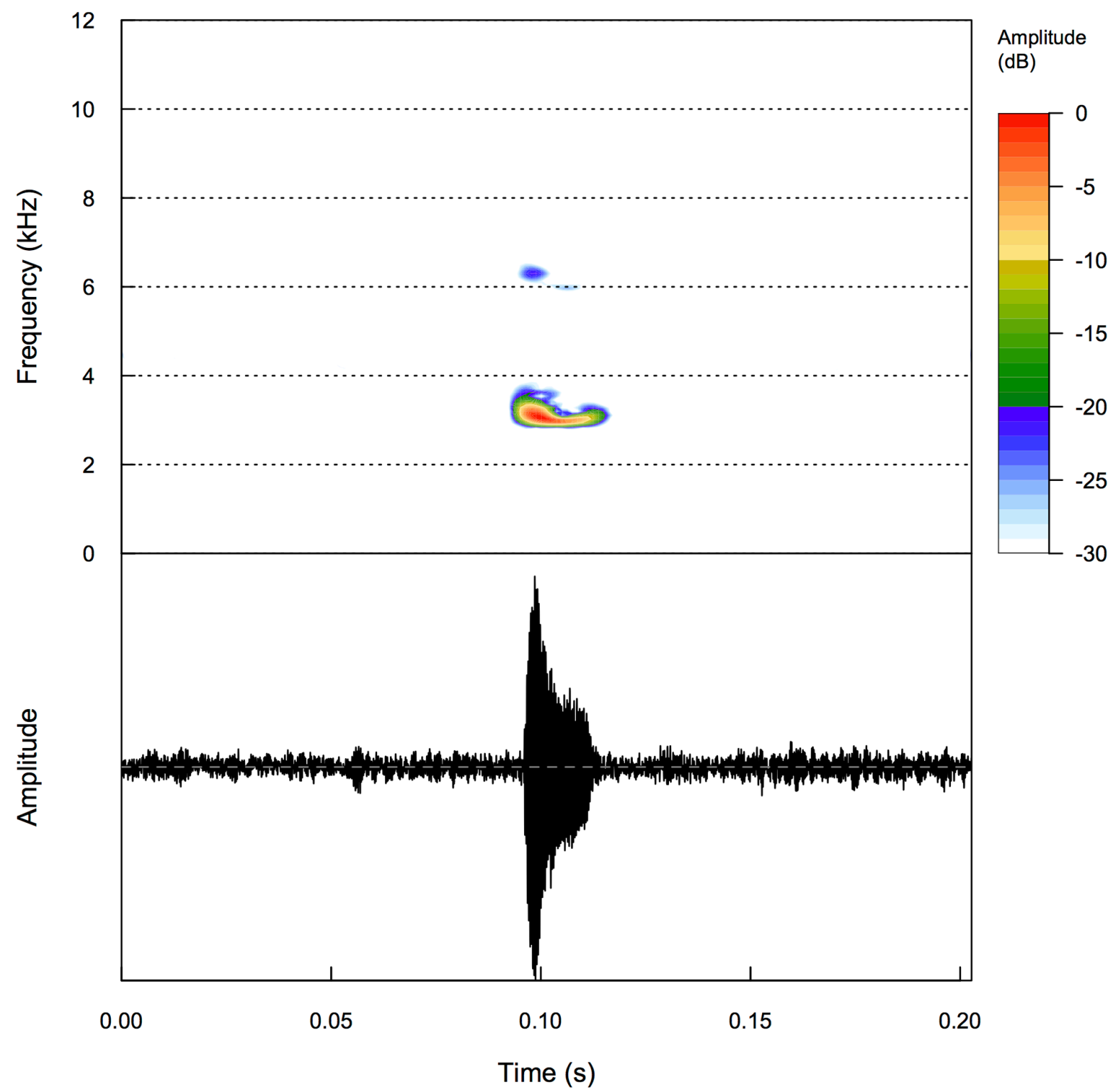

Fig. 8. Vocalization of Pristimantis marmoratus (Boulenger, 1900); oscillogram and spectrogram obtained using Seewave v. 1.6.4 in R. Spectrogram (top) and oscillogram (below) of one call of IRSNB 14472 from Kaieteur National Park, Guyana. Call recorded at a temperature of $24^{\circ} \mathrm{C}$. 
McDiarmid \& Donnelly (2005). Its occurrence in northern Brazil is very likely, since parts of the slopes of Maringma-tepui are in Brazil (Fig. 1).

\section{Natural history}

All specimens were found in undisturbed submontane or montane rainforest (Fig. 9), active on small trees $50-300 \mathrm{~cm}$ above the ground, exclusively at dusk. Pristimantis marmoratus is not a common species; only a few specimens have been found at each locality of occurrence. Males were found calling (in June and November) upside down from mossy tree trunks of low diameter $(<10 \mathrm{~cm})$ between 120 and $300 \mathrm{~cm}$ above the ground, except one male (IRSNB 14473), which was calling from the top of a green leaf $50 \mathrm{~cm}$ above the ground. The "upside down" call posture is also found in the closely related $P$. sp. 1 of Fouquet et al. (2013) (as recovered in our preliminary molecular phylogenetic analysis, see below), and in $P$. espedeus and $P$. inguinalis.

In June 2012, which corresponds to the rainy season in the area, a cluster of four Pristimantis marmoratus eggs (Fig. 6B) was found by one of us (DBM) attached to the inside part of a leaf of a bromeliad, Guzmania cf. sphaeroidea (André) André ex Mez (Fig. 6A), $150 \mathrm{~cm}$ above the ground, on Mount Kopinang, Wokomung Massif, near the top of Kamana Falls at about 1600 m elevation $\left(04^{\circ} 59^{\prime} 58^{\prime \prime}\right.$ $\left.\mathrm{N}, 59^{\circ} 52^{\prime} 49^{\prime \prime} \mathrm{W}\right)$. Molecular analyses confirmed conspecificity of these eggs with P. marmoratus (Appendix 3). The large, white eggs did not have visibly developed embryos. After photographing

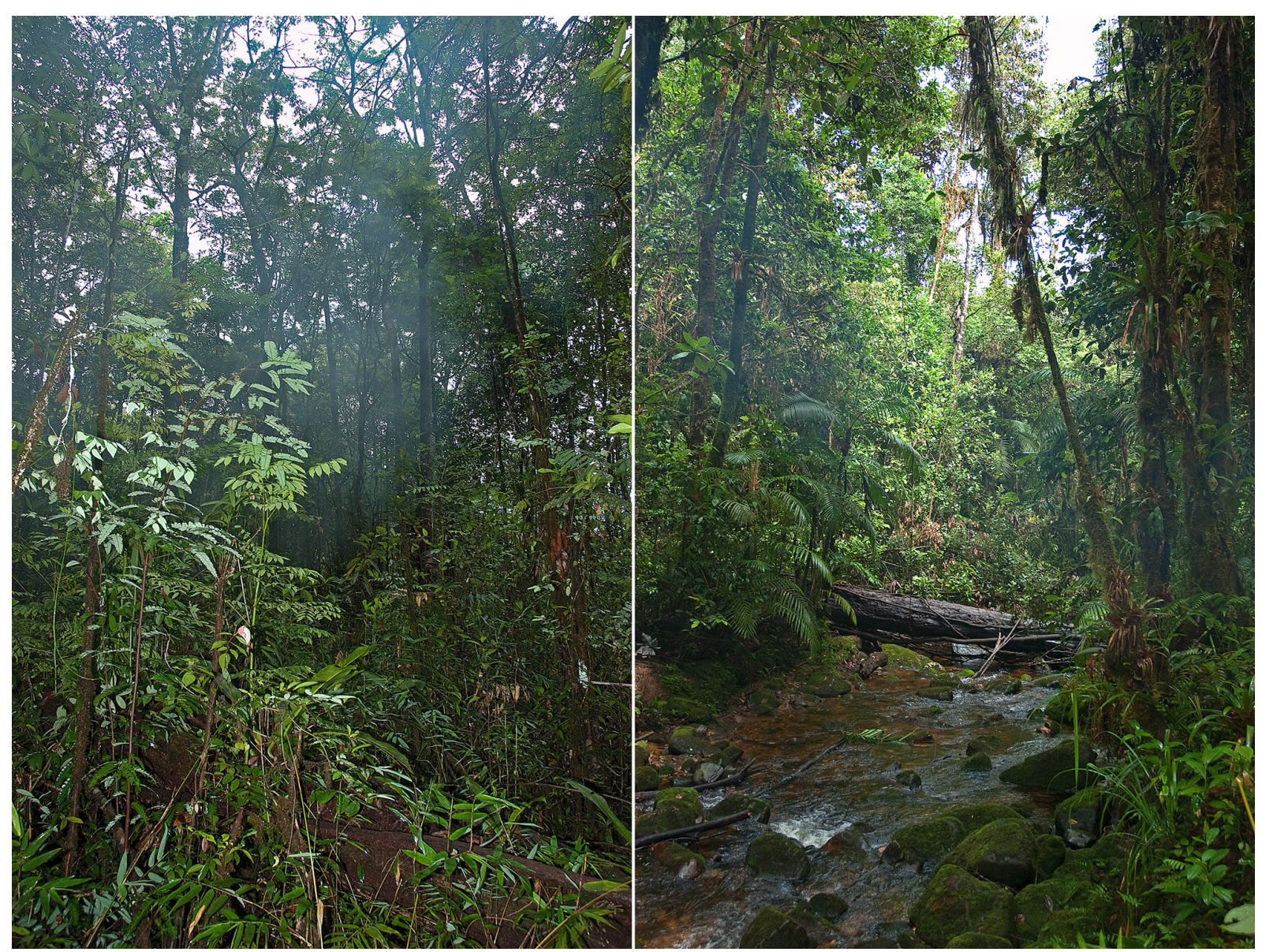

Fig. 9. Habitat of Pristimantis marmoratus (Boulenger, 1900). Left. Submontane rainforest in Kaieteur National Park at ca 630 m elevation. Right. Montane rainforest on the slopes of Maringma-tepui, Guyana at ca 1376 m elevation. Photographs by PJRK. 
and preserving the eggs, the small plant was investigated for inhabitants of the aquatic portion of the phytotelmata. Immediately a small frog jumped out and disappeared into the deep ground litter, and eggs and tadpoles of Anomaloglossus beebei (Noble, 1923) were found in the water of the phytotelmata of the same small bromeliad and in the water of five other bromeliads nearby (egg/frog identifications confirmed by molecular analyses). Pristimantis marmoratus and Anomaloglossus beebei thus share the same bromeliad as an oviposition site on the Wokomung Massif (Fig. 6C). Other Pristimantis species found in syntopy with P. marmoratus were P. dendrobatoides (above $1600 \mathrm{~m}$ elevation), P. jester (above $1300 \mathrm{~m}$ elevation), P. saltissimus (above $1000 \mathrm{~m}$ elevation), and P. pulvinatus (above $1000 \mathrm{~m}$ elevation).

\section{Phylogenetic relationships}

Other Pristimantis species have often been confused with Pristimantis marmoratus (see below and Table 1). Available phylogenetic analyses using samples from misidentified specimens are thus unreliable for that taxon (e.g., Hedges et al. 2008; Pyron \& Wiens 2011; Canedo \& Haddad 2012; Kok et al. 2012; Padial et al. 2014; Mendoza et al. 2015; see below).

Our molecular phylogenetic analysis based on a single mitochondrial gene (16S) of correctly identifiedor reidentified - specimens of the Pristimantis "unistrigatus group" in the Guiana Shield recovered Pristimantis marmoratus as unambiguously distinct from all the other included members of the group (Fig. 10). The gene fragment we used is short and many members of the "unistrigatus group" occurring outside the Guiana Shield have not been included. Therefore, our analysis remains limited in deciphering the phylogenetic position and affinities of P. marmoratus with the other species of the genus. Nevertheless, our analysis recovered P. marmoratus as the sister species (with strong support, $\mathrm{pp}=0.98$ ) of an unnamed Pristimantis species from the lowlands of French Guiana and Amapá State (Brazil), called $P$. sp. 1 by Fouquet et al. (2013). However, the lowest genetic distances (0.077) are found between P. marmoratus and other Pantepui species (P. abakapa and P. sp. Ayanganna, see Table 3).

\section{Discussion}

Confusion between Pristimantis marmoratus and similar or undescribed species has been common in the literature. This is not surprising because in preservative some species are very hard (if not impossible) to distinguish since some important diagnostic characters may disappear (e.g., colour pattern, colour of iris, skin texture). Reports of P. marmoratus in French Guiana by Lescure (1981) for example, and later by Lescure \& Marty (2001), correspond to at least two different undescribed lowland species (Fouquet et al. 2013); reports of P. marmoratus from the slopes of Marahuaka-tepui, Amazonas State in Venezuela (Rivero 1961), the Mabura Hill Forest Reserve in central Guyana (Ernst et al. 2005), Suriname (Ouboter \& Jairam 2012), Amapá State in Brazil (Dias Lima 2008) and northern Pará State in Brazil (Avila-Pires et al. 2010) are most probably the result of misidentifications with other related species.

Kok et al. (2012, suppl. info.) presented a molecular phylogenetic tree showing that two specimens of "P. pulvinatus" from La Escalera in Venezuela (type locality of the species) fall into two different clades, suggesting the occurrence of two morphologically similar species in that region. In fact, Duellman's (1997) report of P. pulvinatus in La Escalera, is based on both P. pulvinatus and P. marmoratus (KU18105 was not examined by us, but is reidentified here as $P$. marmoratus based on molecular data); Hedges et al. (2008) provided a sequence of P. pulvinatus from La Escalera, Venezuela, based on a misidentified specimen of $P$. marmoratus (KU18105, see above) and a sequence of P. marmoratus from Guyana based on a misidentified specimen of $P$. saltissimus; Kok \& Kalamandeen's (2008) report of $P$. inguinalis from Kaieteur National Park, Guyana, is exclusively based on specimens of P. marmoratus (these authors have been confused by the extreme similarity of the calls of these species and by the yellowish wash on the groin in P. marmoratus); Pyron \& Wiens (2011) inferred the phylogenetic position of P. marmoratus 
based on two misidentified specimens, one being $P$. saltissimus and the other one being the $P$. sp 1 of Fouquet et al. (2013); Kok et al. (2012) provided a sequence of $P$. cf. marmoratus from French Guiana based on a misidentified juvenile specimen of $P$. inguinalis; Cole et al. (2013, plate 17 E) provided a photograph of $P$. marmoratus from Guyana that corresponds to $P$. saltissimus, and a photograph of $P$. saltissimus from Guyana (plate $17 \mathrm{~F}$ ) that corresponds to P. marmoratus. Canedo \& Haddad (2012), Padial et al. (2014) and Mendoza et al. (2015) inferred the phylogenetic position of $P$. marmoratus based on a sample assigned to $P$. saltissimus. Several incorrect identifications thus occur in GenBank; reidentifications are provided in Table 1.

Because the report of Pristimantis inguinalis from Kaieteur National Park in Guyana (Kok \& Kalamandeen 2008) is in error (see above), the distribution of $P$. inguinalis is likely restricted to the eastern Guiana Shield lowlands, east of the Essequibo River (Guyana).

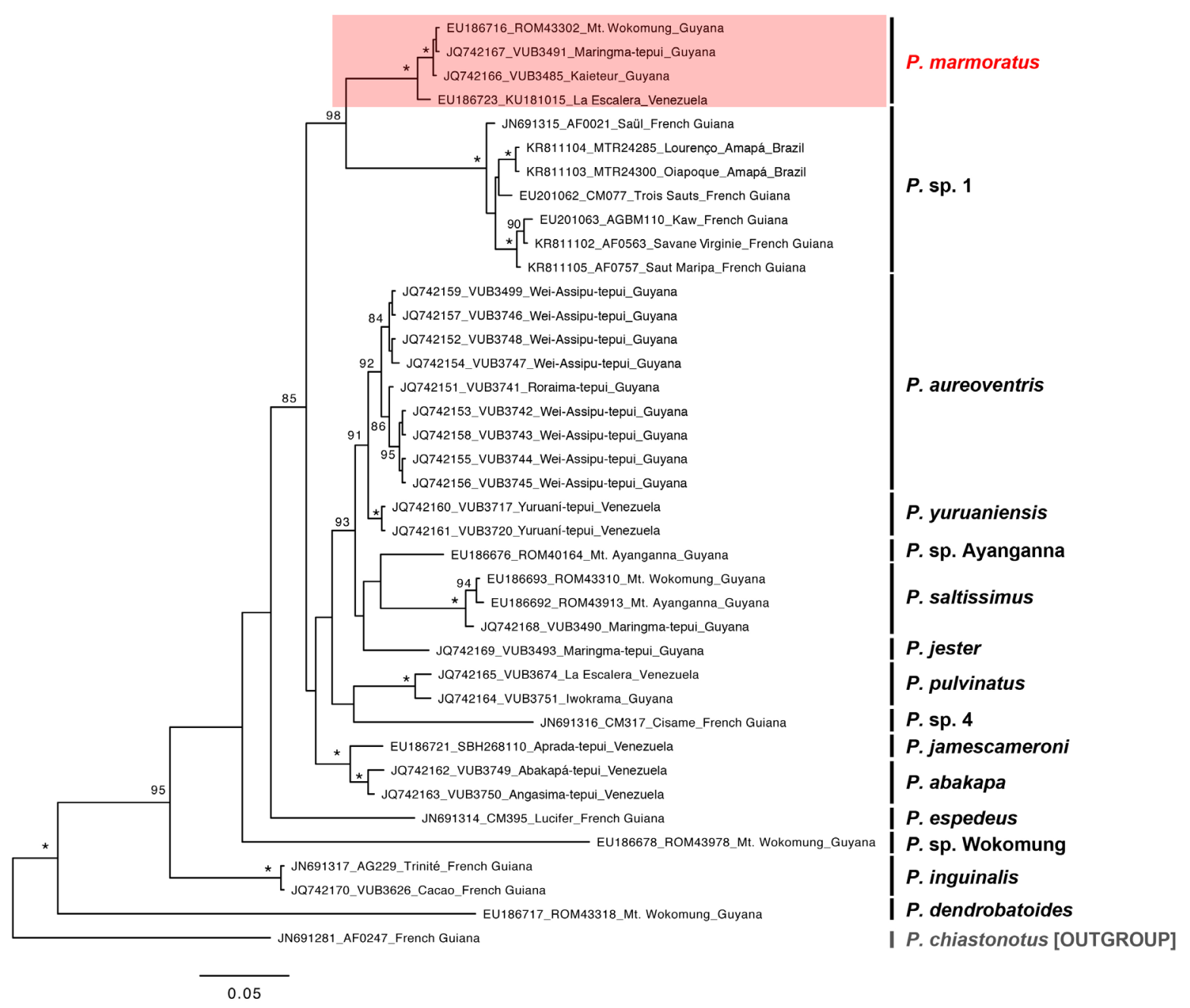

Fig. 10. Phylogenetic relationships within the Pristimantis "unistrigatus group" in the Guiana Shield as recovered in the MrBayes analysis (438 bp of the 16S rRNA gene sequence). Values at each node represent statistical support $(*=0.99$ or 1). Pristimantis marmoratus (Boulenger, 1900) is highlighted in red. 
Table 3. Mean genetic distances (p-distances) among major lineages of the Pristimantis "unistrigatus group" in the Guiana Shield using pairwise deletion.

\begin{tabular}{|c|c|c|c|c|c|c|c|c|c|c|c|c|c|c|}
\hline & 1 & 2 & 3 & 4 & 5 & 6 & 7 & 8 & 9 & 10 & 11 & 12 & 13 & 14 \\
\hline \multicolumn{15}{|l|}{1 P. marmoratus } \\
\hline 2 P. abakapa & 0.077 & & & & & & & & & & & & & \\
\hline $3 P$. sp. Ayanganna & 0.077 & 0.063 & & & & & & & & & & & & \\
\hline $4 P$. aureoventris & 0.080 & 0.053 & 0.036 & & & & & & & & & & & \\
\hline 5 P. yuruaniensis & 0.080 & 0.053 & 0.038 & 0.015 & & & & & & & & & & \\
\hline 6 P. jamescameroni & 0.089 & 0.026 & 0.072 & 0.063 & 0.060 & & & & & & & & & \\
\hline 7 P. pulvinatus & 0.097 & 0.064 & 0.064 & 0.063 & 0.060 & 0.062 & & & & & & & & \\
\hline 8 P. jester & 0.099 & 0.077 & 0.063 & 0.047 & 0.048 & 0.084 & 0.078 & & & & & & & \\
\hline 9 P. inguinalis & 0.113 & 0.104 & 0.116 & 0.113 & 0.121 & 0.114 & 0.121 & 0.126 & & & & & & \\
\hline 10 P. saltissimus & 0.113 & 0.077 & 0.067 & 0.059 & 0.053 & 0.078 & 0.078 & 0.079 & 0.140 & & & & & \\
\hline 11 P. espedeus & 0.115 & 0.112 & 0.119 & 0.121 & 0.124 & 0.127 & 0.116 & 0.145 & 0.133 & 0.136 & & & & \\
\hline 12 P. sp. 1 & 0.121 & 0.108 & 0.123 & 0.108 & 0.115 & 0.109 & 0.116 & 0.137 & 0.133 & 0.129 & 0.143 & & & \\
\hline 13 P. sp. 4 & 0.126 & 0.102 & 0.113 & 0.102 & 0.099 & 0.101 & 0.106 & 0.106 & 0.138 & 0.126 & 0.144 & 0.138 & & \\
\hline 14 P. sp. Wokomung & 0.183 & 0.168 & 0.164 & 0.160 & 0.171 & 0.161 & 0.155 & 0.176 & 0.173 & 0.182 & 0.168 & 0.188 & 0.167 & \\
\hline 15 P. dendrobatoides & 0.211 & 0.217 & 0.206 & 0.210 & 0.216 & 0.219 & 0.220 & 0.216 & 0.213 & 0.216 & 0.204 & 0.219 & 0.203 & 0.216 \\
\hline
\end{tabular}

Given our results, the taxonomic status of Hylodes grandoculis Van Lidth de Jeude, 1904 [a synonym of P. marmoratus according to Hoogmoed (in Frost 1985)] from the Coppename basin in Suriname should be reassessed.

Pristimantis marmoratus is currently listed as Least Concern (LC) "in view of its wide distribution, tolerance of a degree of habitat modification, presumed large population, and because it is unlikely to be declining to qualify for listing in a more threatened category" (MacCulloch et al. 2010). Our study indicates that $P$. marmoratus has a more restricted range than previously thought, and we cannot confirm any tolerance to habitat modification (the species is restricted to pristine submontane and montane rainforests within its known range). However, since the distribution of $P$. marmoratus spans over relatively untouched areas of the Eastern Pantepui District and no decline could be demonstrated so far, we suggest maintaining its IUCN conservation status as LC, a category that applies to taxa that do not qualify (and are not close to qualifying) as Threatened or Near Threatened (IUCN Standards and Petitions Subcommittee 2016).

\section{Acknowledgements}

PJRK's work in Pantepui was/is supported by postdoctoral fellowships from the Fonds voor Wetenschappelijk Onderzoek Vlaanderen (FWO12A7614N/FWO12A7617N). Permission to conduct research in indigenous lands in the Pakaraima Mountains of Guyana was granted by the Guyanese Ministry of Amerindian Affairs. Research and export permits were issued by the Guyana Environmental Protection Agency, which is here warmly acknowledged. The field assistance of P. Benjamin, the late C. Perry, and G. "Kinky" Seegobin was invaluable. We thank the following curators and collection managers who allowed access to collections under their care: R. Ernst (Senckenberg Naturhistorische Sammlungen Dresden, Germany), B. Clarke (Natural History Museum, London, UK), and D. Kizirian (American Museum of Natural History, New York, USA). Examination of museum specimens at the Natural History Museum in London was made possible thanks to a Synthesys grant (GB-TAF-4794) from the Synthesys Project http://www.synthesys.info, which is financed by European Community 
Research Infrastructure Action under the FP6 "Structuring the European Research Area" Programme. The bromeliad was kindly identified by Bruce Holst (Marie Selby Botanical Gardens, Florida, USA). This study was made possible with the generous support of the Belgian Directorate-General of Development Cooperation and the King Léopold III Funds for Nature Exploration and Conservation to PJRK. DBM's research in Pantepui was supported by grants from the National Geographic Society, Smithsonian Institution, and Conservation International. AF's work benefited from an "Investissement d'Avenir" grant managed by Agence Nationale de la Recherche (CEBA, ref. ANR-10-LABX-25-01), France.

\section{References}

Avila-Pires T.C.S., Hoogmoed M.S. \& Rocha W.A. 2010. Notes on the vertebrates of northern Pará, Brazil: a forgotten part of the Guianan Region, I. Herpetofauna. Boletim do Museu Paraense Emilio Goeldi. Ciências Naturais 5 (1): 13-112.

Barrio-Amorós C.L. 1998. Sistemática y biogeografía de los anfibios (Amphibia) de Venezuela. Acta Biologica Venezuélica 18 (2): 1-93.

Bossuyt F. \& Milinkovitch M.C. 2000. Convergent adaptive radiations in Madagascan and Asian ranid frogs reveal covariation between larval and adult traits. Proceedings of the National Academy of Sciences 97: 6585-6590. https://doi.org/10.1073/pnas.97.12.6585

Boulenger G.A. 1900. Batrachians. In: Lankester E.R. (ed.) Report on a collection made by Messrs. McConnell, F.V. \& Quelch J.J. at Mount Roraima in British Guiana. Transactions of the Linnean Society of London, Series 2, Zoology 8: 55-56. https://doi.org/10.1111/j.1096-3642.1900.tb00308.x

Brown N.E. and others (sic). 1901. Report on two botanical collections made by Messrs. F.V. McConnell and J.J. Quelch at Mount Roraima in British Guiana. Transactions of the Linnean Society of London, Series 2, Botany 6: 1-107. https://doi.org/10.1111/j.1095-8339.1901.tb00001.x

Canedo C. \& Haddad C.F.B. 2012. Phylogenetic relationships within anuran clade Terrarana, with emphasis on the placement of Brazilian Atlantic rainforest frogs genus Ischnocnema (Anura: Brachycephalidae). Molecular Phylogenetics and Evolution 65: 610-620.

https://doi.org/10.1016/j.ympev.2012.07.016

Charif R.A., Waack A.M. \& Strickman L.M. 2010. Raven Pro 1.4 User's Manual. Cornell Laboratory of Ornithology, Ithaca, NY.

Chubb C. 1921. The Birds of British Guiana. Volume 2. Bernard Quaritch, London.

Cole C.J., Townsend C.R., Reynolds R.P., MacCulloch R.D. \& Lathrop A. 2013. Amphibians and reptiles of Guyana, South America: illustrated keys, annotated species accounts, and a biogeographic synopsis. Proceedings of the Biological Society of Washington 125 (4): 317-620.

https://doi.org/10.2988/0006-324X-125.4.317

Darriba D., Taboada G.L., Doallo R. \& Posada D. 2012. jModelTest 2: More models, new heuristics and parallel computing. Nature Methods 9: 772. https://doi.org/10.1038/nmeth.2019

Dias Lima J. 2008. A herpetofauna do Parque Nacional do Montanhas do Tumucumaque, Amapá, Brasil, Expedições I a V. In: Bernard E. (ed.) Inventários Biológicos Rápidos no Parque Nacional Montanhas do Tumucumaque, Amapá, Brasil. RAP Bulletin of Biological Assessment 48: 38-50.

Duellman W.E. 1997. Amphibians of La Escalera Region, southeastern Venezuela: taxonomy, ecology, and biogeography. Scientific Papers of the Natural History Museum of the University of Kansas 2: 1-52.

Duellman W.E. \& Lehr E. 2009. Terrestrial-breeding frogs (Strabomantidae) in Peru. NTV Science, Münster, Germany. 
Ernst R., Rödel M. \& Arjoon D. 2005. On the cutting edge - The anuran fauna of the Mabura Hill Forest Reserve, Central Guyana. Salamandra 41(4): 179-194.

Fouquet A., Gilles A., Vences M., Marty C., Blanc M. \& Gemmell N.J. 2007. Underestimation of species richness in Neotropical frogs revealed by mtDNA analyses. PLOS ONE 2 (10): e1109. https://doi.org/10.1371/journal.pone.0001109

Fouquet A., Martinez Q., Courtois E.A., Dewynter M., Pineau K., Gaucher P., Blanc M., Marty C. \& Kok P.J.R. 2013. A new species of the genus Pristimantis (Amphibia, Craugastoridae) associated with the moderately elevated massifs of French Guiana. Zootaxa 3750: 569-586.

https://doi.org/10.11646/zootaxa.3750.5.8

Fouquet A., Martinez Q., Zeidler L., Courtois E.A., Gaucher P., Blanc M., Dias Lima J., Marques Souza S., Rordrigues M.T. \& Kok P.J.R. 2016. Cryptic diversity in the Hypsiboas semilineatus species group (Amphibia, Anura) with the description of a new species from the eastern Guiana Shield. Zootaxa 4084: 79-104. https://doi.org/10.11646/zootaxa.4084.1.3

Frost D.R. (1985) Amphibian Species of the World. A Taxonomic and Geographical Reference. Allen Press, Lawrence, Kansas, U.S.A.

Frost D.R. (2016) Amphibian Species of the World: an Online Reference. Version 6.0, American Museum of Natural History, New York, USA. Available from http://research.amnh.org/herpetology/amphibia/ index.html [accessed 1 Aug. 2016].

Guayasamin J.M., Krynak T., Krynak K., Culebras J. \& Hutter C.R. 2015. Phenotypic plasticity raises questions for taxonomically important traits: a remarkable new Andean rainfrog (Pristimantis) with the ability to change skin texture. Zoological Journal of the Linnean Society 173: 913-928. https://doi.org/10.1111/zoj.12222

Hedges S.B., Duellman W.E. \& Heinicke M.P. 2008. New World direct-developing frogs (Anura: Terrarana): Molecular phylogeny, classification, biogeography, and conservation. Zootaxa 1737: 1-182.

Huelsenbeck J.P. \& Ronquist F. 2001. MRBAYES: Bayesian inference of phylogenetic trees. Bioinformatics 17: 754-755.

IUCN Standards and Petitions Subcommittee. 2016. Guidelines for Using the IUCN Red List Categories and Criteria. Version 12. Prepared by the Standards and Petitions Subcommittee. Available from http://www.iucnredlist.org/documents/RedListGuidelines.pdf [accessed 27 Oct. 2017]

Katoh K. \& Standley D.M. 2013. MAFFT Multiple Sequence Alignment Software Version 7: improvements in performance and usability. Molecular Biology and Evolution 30: 772-780. https://doi.org/10.1093/molbev/mst010

Köhler J., Jansen M., Rodríguez A., Kok P.J.R., Toledo L.F., Emmrich M., Glaw F., Haddad C.F.B., Rödel M.-O. \& Vences M. 2017. The use of bioacoustics in anuran taxonomy: theory, terminology, methods and recommendations for best practice. Zootaxa 4251: 1-124.

https://doi.org/10.11646/zootaxa.4251.1.1

Kok P.J.R. 2013. Two new charismatic Pristimantis species (Anura: Craugastoridae) from the tepuis of the "Lost World" (Pantepui region, South America). European Journal of Taxonomy 60: 1-24. https://doi.org/10.5852/ejt.2013.60

Kok P.J.R. \& Barrio-Amorós C.L. 2013. On the taxonomic validity of Pristimantis tepuiensis (Schlüter \& Rödder, 2007) and P. stegolepis (Schlüter \& Rödder, 2007), with remarks on the type series of P. guaiquinimensis (Schlüter \& Rödder, 2007). Zootaxa 3694: 75-80.

https://doi.org/10.11646/zootaxa.3694.1.6 
Kok P.J.R. \& Kalamandeen M. 2008. Introduction to the Taxonomy of the Amphibians of Kaieteur National Park, Guyana. Abc Taxa 5, Royal Belgian Institute of Natural Sciences, Brussels.

Kok P.J.R., Means D.B. \& Bossuyt F. 2011. A new highland species of Pristimantis Jiménez de la Espada, 1871 (Anura: Strabomantidae) from the Pantepui region, northern South America. Zootaxa 2934: 1-19.

Kok P.J.R., MacCulloch R.D., Gaucher P., Poelman E.H., Bourne G.R., Lathrop A. \& Lenglet G.L. 2006. A new species of Colostethus (Anura, Dendrobatidae) from French Guiana with a redescription of Colostethus beebei (Noble, 1923) from its type locality. Phyllomedusa 5: 43-66.

Kok P.J.R., MacCulloch R.D., Means D.B., Roelants K., Van Bocxlaer I. \& Bossuyt F. 2012. Low genetic diversity in tepui summit vertebrates. Current Biology 22: R589-R590.

https://doi.org/10.1016/j.cub.2012.06.034

Kok P.J.R., Willaert B. \& Means D.B. 2013. A new diagnosis and description of Anomaloglossus roraima (La Marca, 1998) (Anura: Aromobatidae: Anomaloglossinae), with description of its tadpole and call. South American Journal of Herpetology 8(1): 29-45. https://doi.org/10.2994/SAJH-D-12-00021.1

Lescure J. 1976. Contribution à l'étude des amphibiens de Guyane Française. VI. Liste préliminaire des anoures. Bulletin du Museum National d'Histoire Naturelle, Série 3, Zoologie 377: 475-524.

Lescure J. 1981. Contribution à l'étude des amphibiens de Guyane Française. VII. Les Eleutherodactylus (Anura, Leptodactylidae). Revue française d'Aquariologie 8: 25-32.

Lescure J. \& Marty C. 2001. Atlas des Amphibiens de Guyane. Patrimoines Naturels, Muséum national d'Histoire naturelle, Paris.

MacCulloch R.D. \& Lathrop A. 2009. Herpetofauna of Mount Ayanganna, Guyana. Results of the Royal Ontario Museum Ayanganna Expedition 2000. Royal Ontario Museum Science Contributions 4: 1-36.

MacCulloch R., Reynolds R., Rodrigues M.T. \& Mijares A. 2010. Pristimantis marmoratus. The IUCN Red List of Threatened Species 2010: e.T56743A11529534.

https://doi.org/10.2305/IUCN.UK.2010-2.RLTS.T56743A11529534.en

Marty C. \& Gaucher P. 1999. Guide sonore des Amphibiens Anoures de Guyane. CD audio. CEBA, Mens, France.

McDiarmid R.W. \& Donnelly M.A. 2005. The herpetofauna of the Guayana Highlands: amphibians and reptiles of the Lost World. In: Donnelly M.A., Crother B.I., Guyer C., Wake M.H. \& White M.E. (eds) Ecology and Evolution in the Tropics: A Herpetological Perspective: 461-560. University of Chicago Press, Chicago.

Mendoza Á.M, Ospina O.E., Cárdenas-Henao H. \& García-R.J.C. 2015. A likelihood inference of historical biogeography in the world's most diverse terrestrial vertebrate genus: Diversification of direct-developing frogs (Craugastoridae: Pristimantis) across the Neotropics. Molecular Phylogenetics and Evolution 85: 50-58. https://doi.org/10.1016/j.ympev.2015.02.001

Myers C.W. \& Donnelly M.A. 2001. Herpetofauna of the Yutajé-Corocoro massif, Venezuela: second report from the Robert G. Goelet American Museum-Terramar expedition to the Northwestern tepuis. Bulletin of the American Museum of Natural History 261: 1-85.

Ouboter P.E. \& Jairam R. 2012. Amphibians of Suriname. Brill Academic Publishers, Leiden.

Padial J.M., Grant T. \& Frost D.R. 2014. Molecular systematics of terraranas (Anura: Brachycephaloidea) with an assessment of the effects of alignment and optimality criteria. Zootaxa 3825: 1-132. https://doi.org/10.11646/zootaxa.3825.1.1 
Phelps W.H. 1938. The geographical status of the birds collected at Mount Roraima. Boletin de la Sociedad Venezolana de Ciencias Naturales 36: 83-95.

Pyron R.A. \& Wiens J.J. 2011. A large-scale phylogeny of Amphibia including over 2800 species, and a revised classification of extant frogs, salamanders, and caecilians. Molecular Phylogenetics and Evolution 61: 543-583. https://doi.org/10.1016/j.ympev.2011.06.012

Rambaut A. 2014. Figtree, a graphical viewer of phylogenetic trees.

Available from http://tree.bio.ed.ac.uk/software/gtree [accessed 6 Sep. 2016].

Rambaut A. \& Drummond A.J. 2007. Tracer version 1.5.

Available from http://tree.bio.ed.ac.uk/software/tracer [accessed 6 Sep. 2016].

R Development Core Team. 2015. R: a language and environment for statistical computing. R Foundation for Statistical Computing, Vienna. Available from http://www.R-project.org [accessed 25 Jul. 2016].

Rivero J.A. 1961. Salientia of Venezuela. Bulletin of the Museum of Comparative Zoology 126: 1-207.

Rivero J.A. 1968. A new species of Eleutherodactylus (Amphibia, Salientia) from the Guayana Region, Edo. Bolívar, Venezuela. Breviora 306: 1-10.

Roelants K., Gower D.J., Wilkinson M., Loader S.P., Biju S.D., Guillaume K., Moriau L. \& Bossuyt F. 2007. Global patterns of diversification in the history of modern amphibians. Proceedings of the National Academy of Sciences 104: 887-892. https://doi.org/10.1073/pnas.0608378104

Simon C., Frati F., Beckenbach A., Crespi B., Liu H. \& Flook P. 1994. Evolution, weighting, and phylogenetic utility of mitochondrial gene sequences and a compilation of conserved polymerase chain reaction primers. Annals of the Entomological Society of America 87: 651-702.

Sueur J., Aubin T. \& Simonis C. 2008. Equipment review: Seewave, a free modular tool for sound analysis and synthesis. Bioacoustics 18 (2): 213-226. https://doi.org/10.1080/09524622.2008.9753600

Tamura K., Peterson D., Peterson N., Stecher G., Nei M. \& Kumar S. 2011. MEGA5: molecular evolutionary genetics analysis using maximum likelihood, evolutionary distance, and maximum parsimony methods. Molecular Biology and Evolution 28: 2731-2739.

https://doi.org/10.1093/molbev/msr121

Tate G.H. 1930. Notes on Mount Roraima region. Geographical Review 20: 312-52.

Vences M., Thomas M., van der Meijden A., Chiari Y. \& Vieites D.R. 2005. Comparative performance of the 16S rRNA gene in DNA barcoding of amphibians. Frontiers in Zoology 2: 5. https://doi.org/10.1186/1742-9994-2-5

Manuscript received: 9 September 2016

Manuscript accepted: 3 May 2017

Published on: 23 January 2018

Topic editor: Rudy Jocqué

Desk editor: Kristiaan Hoedemakers

Printed versions of all papers are also deposited in the libraries of the institutes that are members of the EJT consortium: Muséum national d'Histoire naturelle, Paris, France; Botanic Garden Meise, Belgium; Royal Museum for Central Africa, Tervuren, Belgium; Natural History Museum, London, United Kingdom; Royal Belgian Institute of Natural Sciences, Brussels, Belgium; Natural History Museum of Denmark, Copenhagen, Denmark; Naturalis Biodiversity Center, Leiden, the Netherlands; Museo Nacional de Ciencias Naturales-CSIC, Madrid, Spain; Real Jardín Botánico de Madrid CSIC, Spain. 


\section{Appendix 1}

\section{Additional material examined}

Pristimantis abakapa: VENEZUELA, Estado Bolívar, Abakapá-tepui, IRSNB 15868 (topotypic specimen).

Pristimantis aureoventris: GUYANA, Cuyuni-Mazaruni District, Wei-Assipu-tepui, IRSNB 4152 (holotype), IRSNB 4153-54 (2 paratopotypes).

Pristimantis auricarens: VENEZUELA, Estado Bolívar, Auyán-tepui, A-164951-53 (3 paratopotypes), A-164936-50, A-164954 (16 paratypes).

Pristimantis avius: VENEZUELA, Estado Amazonas, Pico Tamacuari, A-131481 (holotype).

Pristimantis cantitans: VENEZUELA, Estado Amazonas, Cerro Yaví, A-143359-61 (3 paratopotypes).

Pristimantis dendrobatoides: GUYANA, Potaro-Siparuni District, Wokomung Massif, USNM 563662 (holotype), IRSNB 15918 (topotypic specimen).

Pristimantis espedeus: FRENCH GUIANA, Municipality of Régina, Montagne Grande Tortue, R121 (holotype).

Pristimantis guaiquinimensis: VENEZUELA, Estado Bolívar, Guaiquinima-tepui, SMNS 8004.1 (holotype), SMNS 8004.2 (paratype), SMNS 8005 (holotype of P. tepuiensis).

Pristimantis imthurni: VENEZUELA, Estado Bolívar, Aprada-tepui, IRSNB 4165 (holotype).

Pristimantis inguinalis: GUYANA, East Berbice-Corentyne District, New River, BMNH 1939.1.1.1 (holotype), BMNH 1939.1.1.2 (paratype).

Pristimantis jamescameroni: VENEZUELA, Estado Bolívar, Aprada-tepui, IRSNB 4140 (holotype), IRSNB 4161-64 (4 paratopotypes).

Pristimantis jester: GUYANA, Potaro-Siparuni District, Wokomung Massif, USNM 563631 (holotype); Cuyuni-Mazaruni District, slopes of Maringma-tepui, IRSNB 15867, IRSNB 15916-17.

Pristimantis memorans: VENEZUELA, Estado Amazonas, Pico Tamacuari, A-131466 (holotype).

Pristimantis pruinatus: VENEZUELA, Estado Amazonas, Cerro Yaví, A-143362-63 (2 paratopotypes).

Pristimantis pulvinatus: VENEZUELA, Estado Bolívar, La Escalera, IRSNB 15654; GUYANA, Cuyuni-Mazaruni District, slopes of Maringma-tepui, IRSNB 17927.

Pristimantis saltissimus: GUYANA, Potaro-Siparuni District, Wokomung Massif, USNM 563639 (holotype), IRSNB 15644-53 (10 topotypic specimens).

Pristimantis yaviensis: VENEZUELA, Estado Amazonas, Cerro Yaví, A-143364-76 (13 paratopotypes), A-159161-63.

Pristimantis yuruaniensis: VENEZUELA, Estado Bolívar, Yuruaní-tepui, IRSNB 15638-41 (4 topotypic specimens), SMNS 09855 (paratype). 


\section{Appendix 2}

GenBank accession numbers of samples used in the molecular phylogenetic analysis. Samples in boldface represent specimens corresponding to the morphology of the holotype of Pristimantis marmoratus (Boulenger, 1900).

\begin{tabular}{|c|c|c|c|}
\hline Species & Locality & Country & GenBank (16S) \\
\hline P. abakapa & Abakapá-tepui & Venezuela & JQ742162 \\
\hline P. abakapa & Angasima-tepui & Venezuela & JQ742163 \\
\hline P. aureoventris & Wei-Assipu-tepui & Guyana & JQ742159 \\
\hline P. aureoventris & Roraima-tepui & Guyana & JQ742151 \\
\hline P. aureoventris & Wei-Assipu-tepui & Guyana & JQ742153 \\
\hline P. aureoventris & Wei-Assipu-tepui & Guyana & JQ742158 \\
\hline P. aureoventris & Wei-Assipu-tepui & Guyana & JQ742155 \\
\hline P. aureoventris & Wei-Assipu-tepui & Guyana & JQ742156 \\
\hline P. aureoventris & Wei-Assipu-tepui & Guyana & JQ742157 \\
\hline P. aureoventris & Wei-Assipu-tepui & Guyana & JQ742154 \\
\hline P. aureoventris & Wei-Assipu-tepui & Guyana & JQ742152 \\
\hline P. dendrobatoides & Mt. Wokomung & Guyana & EU186717 \\
\hline P. espedeus & Lucifer & French Guiana & JN691314 \\
\hline P. inguinalis & Trinité, Crique Grand Leblond & French Guiana & JN691317 \\
\hline P. inguinalis & Cacao Mountain & French Guiana & JQ742170 \\
\hline P. jamescameroni & Aprada-tepui & Venezuela & EU186721 \\
\hline P. jester & Maringma-tepui & Guyana & JQ742169 \\
\hline P. marmoratus & Mt. Wokomung & Guyana & EU186716 \\
\hline P. marmoratus & Kaieteur National Park & Guyana & JQ742166 \\
\hline P. marmoratus & Maringma-tepui & Guyana & JQ742167 \\
\hline P. marmoratus & La Escalera & Venezuela & EU186723 \\
\hline P. pulvinatus & La Escalera & Venezuela & JQ742165 \\
\hline P. pulvinatus & Iwokrama & Guyana & JQ742164 \\
\hline P. saltissimus & Mt. Wokomung & Guyana & EU186693 \\
\hline P. saltissimus & Mt. Ayanganna & Guyana & EU186692 \\
\hline P. saltissimus & Maringma-tepui & Guyana & JQ742168 \\
\hline P. sp. 1 & Saül & French Guiana & JN691315 \\
\hline P. sp. 1 & Savane Virginie & French Guiana & KR811102 \\
\hline P. sp. 1 & St Georges, Saut Maripa & French Guiana & KR811105 \\
\hline P. sp. 1 & Montagne de Kaw & French Guiana & EU201063 \\
\hline P. sp. 1 & Trois Sauts & French Guiana & EU201062 \\
\hline P. sp. 1 & Amapá, Lourenço & Brazil & KR811104 \\
\hline P. sp. 1 & Amapá, Oiapoque & Brazil & KR811103 \\
\hline P. sp. 4 & Cisame & French Guiana & JN691316 \\
\hline P. sp. Ayanganna & Mt. Ayanganna & Guyana & EU186676 \\
\hline P. sp. Wokomung & Mt. Wokomung & Guyana & EU186678 \\
\hline P. yuruaniensis & Yuruaní-tepui & Venezuela & JQ742160 \\
\hline P. yuruaniensis & Yuruaní-tepui & Venezuela & JQ742161 \\
\hline
\end{tabular}




\section{Appendix 3}

GenBank accession numbers of available and newly generated (in bold) 16S sequences of Pristimantis marmoratus (Boulenger, 1900).

\begin{tabular}{lcccc}
\hline Voucher & Species & Locality & Country & GenBank \\
\hline IRSNB 14471 & P. marmoratus & Kaieteur National Park & Guyana & JQ742166 \\
IRSNB 14472 & P. marmoratus & Kaieteur National Park & Guyana & MF037218 \\
IRSNB 14473 & P. marmoratus & Kaieteur National Park & Guyana & MF037219 \\
IRSNB 14474 & P. marmoratus & Kaieteur National Park & Guyana & MF037220 \\
IRSNB 12862 & P. marmoratus & Maringma-tepui & Guyana & JQ742167 \\
IRSNB 17916 & P. marmoratus & Maringma-tepui & Guyana & MF037221 \\
IRSNB 17939 & P. marmoratus & Maringma-tepui & Guyana & MF037222 \\
CPI 10703 (egg) & P. marmoratus & Wokomung Massif & Guyana & MF037223 \\
KU 181015 & P. marmoratus & La Escalera & Venezuela & EU186723 \\
ROM 43302 & P. marmoratus & Wokomung Massif & Guyana & EU186716 \\
\hline
\end{tabular}

